\title{
6 Globalisation and economic development: Malaysia's experience
}

\author{
Cassey Lee
}

\section{Introduction}

Globalisation has historically played an important role in the emergence of Malaysia as a nation and its subsequent development. Almost every important aspect of globalisation involving trade, capital, labour migration, technology, and information flows has left deep imprints on Malaysia's economy and society. The nature and impact of globalisation, however, have changed over time. These changes include the economic transformation of an economy that was highly dependent on primary commodities (tin and rubber) into one driven by manufactured exports. Waves of migrant workers have also shaped the country into a multi-ethnic society especially since the nineteenth century. The openness of the country's economy in terms of trade and investment has also made it vulnerable to global economic shocks.

The goal of this paper is to examine the impact of globalisation on the Malaysian economy through the different phases of its development experience. This will include socio-economic development (poverty eradication and inequality), structural transformation (industrialisation and deindustrialisation), and vulnerability to external shocks (oil crises and financial crises). The paper will also discuss the country's domestic and external economic policies aimed at meeting domestic needs (affirmative action) and managing the effects of globalisation.

\section{Globalisation and the formation of Malaysia}

The formation of Malaysia as a nation is a useful starting point for analysing the impact of globalisation on the country. Globalisation played an important role in the economic and political history of Malaysia in the pre-colonial, colonial, and post-colonial (independence) periods. In the pre-colonial period from the fifteenth to the eighteenth century, the early states in Peninsular Malaysia such as Melaka and Penang grew as major entrepôts for intra- and inter-regional trade flows. The strategic locations of these port cities together with bountiful natural resources (gold, tin, forest products) in their hinterlands attracted successive and competing colonial powers from the West. 
The Portuguese conquered and occupied Melaka in 1511. The Dutch wrested Melaka from the Portuguese in 1641 and it remained under their control until it was handed over to the British as part of the 1824 Anglo-Dutch Treaty. ${ }^{1}$ Penang came into the possession of the British East India Company when the island was leased from Sultan Abdullah of Kedah in 1786. Melaka and Singapore came under the control of the British East India Company in 1864. Three years later, in 1867, the three entrepôt states became crown colonies (Straits Settlements) and their administration was shifted from Calcutta to London in 1867.

The British colonisation of the rest of Peninsular Malaysia (Malaya) began to take shape in the 1870-80s with the implementation of the Resident System in the states of Perak (in 1874), Selangor (1874), Negeri Sembilan (1887), and Pahang (1888). ${ }^{2}$ Control over these states was subsequently centralised with the formation of the Federated Malay States in 1896. The other Northern Malay states of Perlis, Kedah, Kelantan, and Terengganu came under British control with the signing of the Anglo-Siamese Treaty in 1909. These states, together with Johor, became British protectorates and were collectively known as the Unfederated Malay States. Two other states on Borneo island, namely Sabah and Sarawak, became British protectorates by 1888 . Thus, by the late nineteenth century, all of the states that are part of Malaysia today had come under British control.

British control was disrupted by the Japanese occupation during the Second World War from 1941 to 1945 . In the aftermath of the war, administration of all of the states in Malaya was centralised under British control through the formation of the Malayan Union in 1946. Fierce opposition from the Malay community and Malay rulers led to the replacement of the Malayan Union with the Federation of Malaya in 1948. Malaya gained independence in 1957. In 1963, Singapore, Sabah, and Sarawak joined Malaya to form Malaysia. Two years later in 1965, Singapore exited Malaysia, and the polity of Malaysia has remained unchanged since then.

In summary, the amalgamation of states into the Federation of Malaysia can be seen as part of the globalisation process involving colonialisation and decolonialisation. The political changes that took place during this process were accompanied by significant growth and structural change in the economy.

\section{Trade, growth, and structural change}

Since the country's independence in 1957 and over a period of about 50 years since then, Malaysia has developed to become an upper middle-income developing country. In 1960, the country's gross domestic product (GDP) per capita stood at \$1,354 (in 2010 constant prices), around 10\% of the GDP per capita of the United Kingdom. By 2017, Malaysia's GDP per capita reached \$11,528, about $27 \%$ of the GDP per capita of the United Kingdom (Figure 6.1). How did Malaysia grow to become a middle-income country? Trade has clearly played an important role in the country's growth and development, as can be seen in the country's dependence on it. 


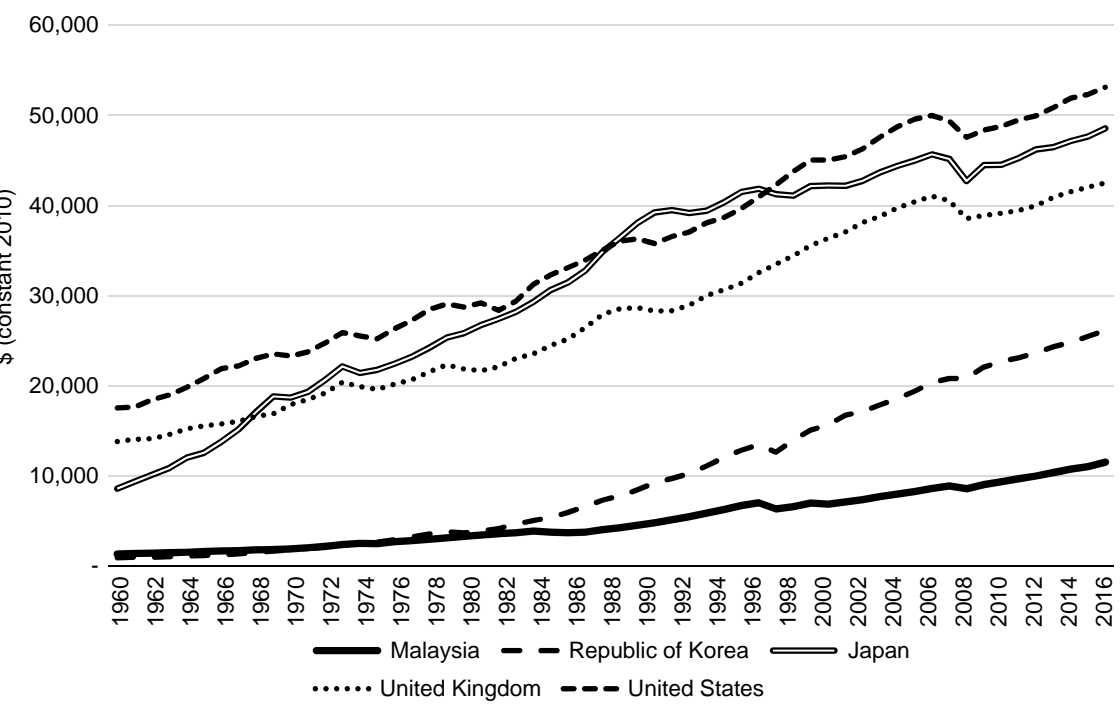

Figure 6.1 Gross Domestic Product Per Capita of Malaysia and Selected Developed Countries, 1960-2017.

Source: World Bank Open Data. https://data.worldbank.org (accessed 30 July 2019).

\subsection{Pre-independence period}

The Malaysian economy has always been very open. Even in the preindependence period, the country's trade ratio (share of trade in GDP) ranged from $80 \%$ to $120 \%$ (Figure 6.2 ). In the post-independence period, Malaysia became even more open. The country's trade ratio rose from around $100 \%$ in the mid-1970s to a peak of $220 \%$ in 2000 (Figure 6.3). Thereafter, the country's trade ratio began to decline due to deindustrialisation. Despite this, the country's economy remains very open with a trade ratio of around $135 \%$.

With trade as a major source of growth, the country did experience fairly high growth rates during the pre-independence period (Figure 6.4). However, economic growth during this period was very erratic. A major source of this instability was the importance of primary commodities such as tin and rubber as major sources of exports. These two commodities accounted for close to $80 \%$ of total exports during this period (Figure 6.5). Fluctuations in the prices of these commodities affected the country's economy.

Tin was an important industry in the late 1880s. Although tin had been mined in Malaya for hundreds of years, the discovery of tin in Perak in 1840 led to a rapid expansion of the industry through the mid-1890s. The tin industry also developed rapidly in other states, such as Selangor, Negeri Sembilan, and Pahang. The Second World War adversely affected tin production, but production recovered after the war, reaching a peak around 1970 and declining thereafter. 


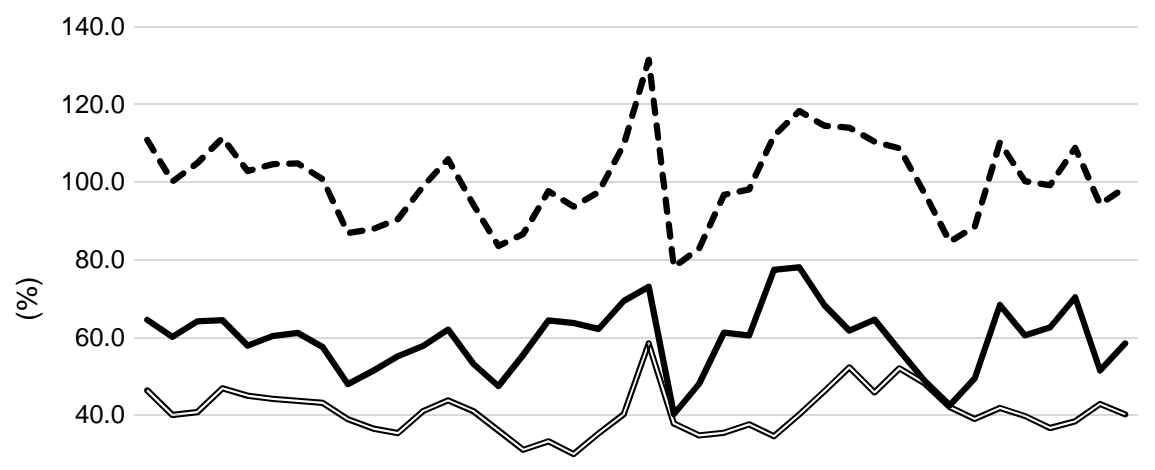

20.0

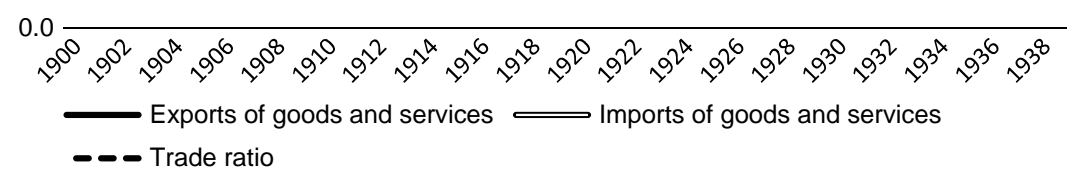

Figure 6.2 Share of Imports and Exports in Gross Domestic Product - Malaya, 1900-39.

Source: Economic History of Malaya. https://www.ehm.my/home (accessed 30 July 2019).

The decline in the importance of tin production and exports were offset by the rising importance of rubber exports, especially after the 1890s. The rubber industry grew rapidly in the states of Selangor, Perak, and Negeri Sembilan from 1905 , but stagnated during the Japanese occupation and during the 1950s due to competition from synthetic rubber. However, the industry grew rapidly from the 1960s through the mid-1980s. The rubber industry only began to stagnate and decline after the mid-1980s (Figure 6.6).

\subsection{Post-independence period}

The subsequent decline of tin and rubber as sources of exports did not spell doom for the Malaysian economy in the post-independence years. Economic growth became more robust and less volatile in some periods. Although external global shocks such as the oil crisis in the 1970s and the Asian financial crisis in the 1990s did affect the Malaysian economy, it managed to maintain relatively robust growth during intermittent periods (Figure 6.7). For example, the average growth rate was $10 \%$ during $1988-96$.

The relatively robust growth rates achieved in some periods in the postindependence era were made possible by the economic diversification strategies pursued and promoted by the Government of Malaysia. These strategies included 


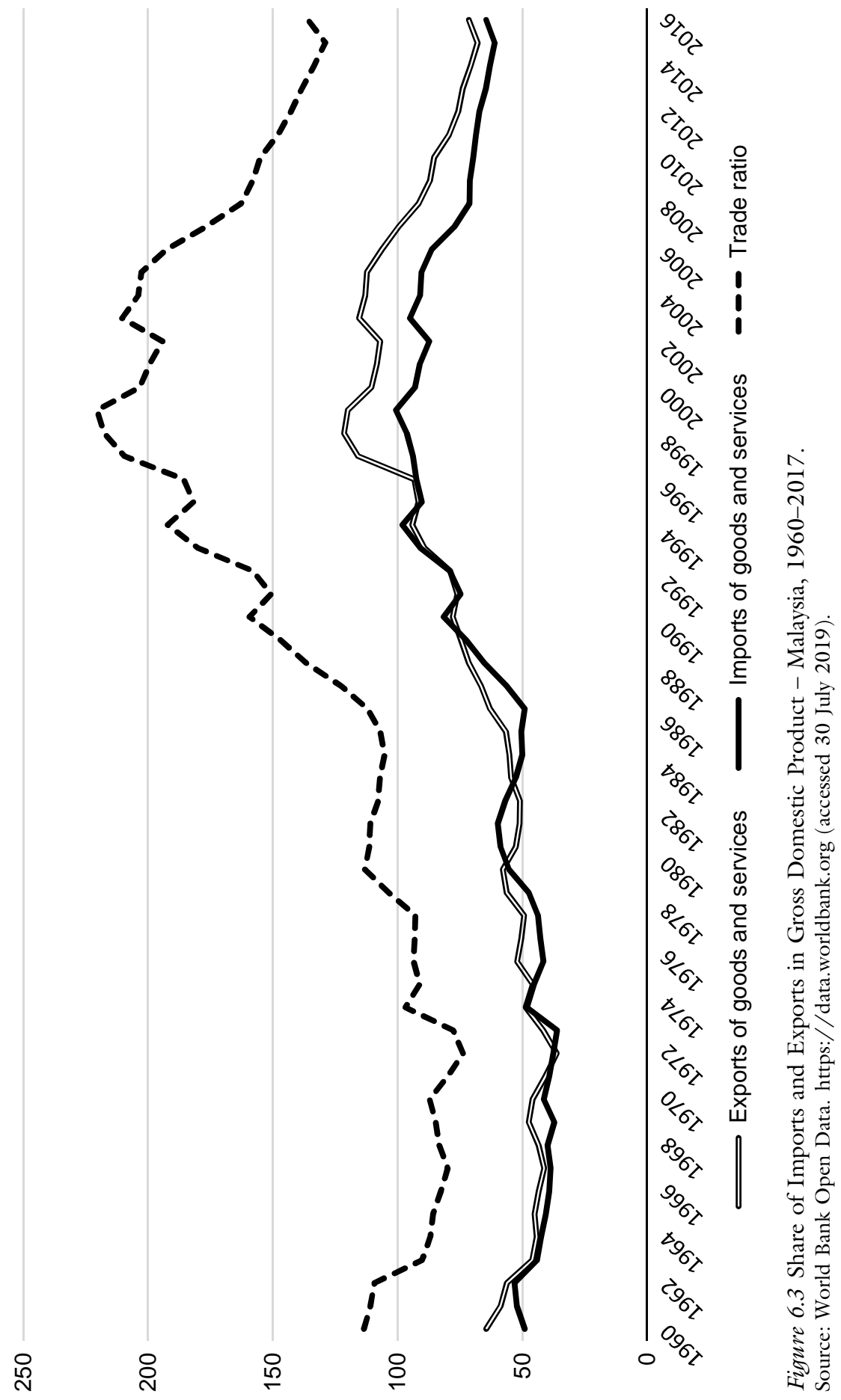




\section{Cassey Lee}

15

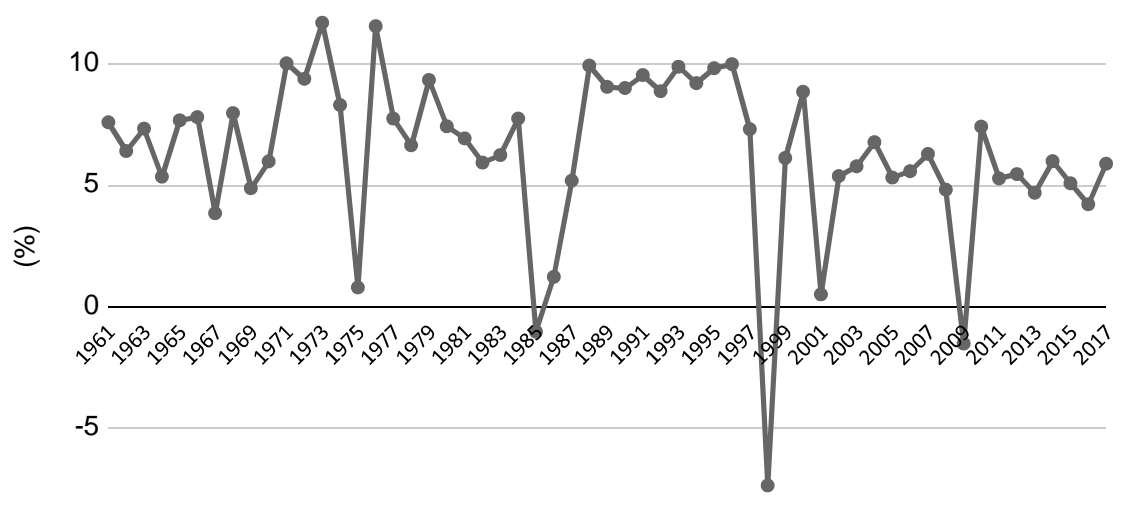

$-10$

Figure 6.4 Annual Real Gross Domestic Product Growth - Malaya, 1901-39.

Source: Economic History of Malaya. https://www.ehm.my/home (accessed 30 July 2019).

120.0

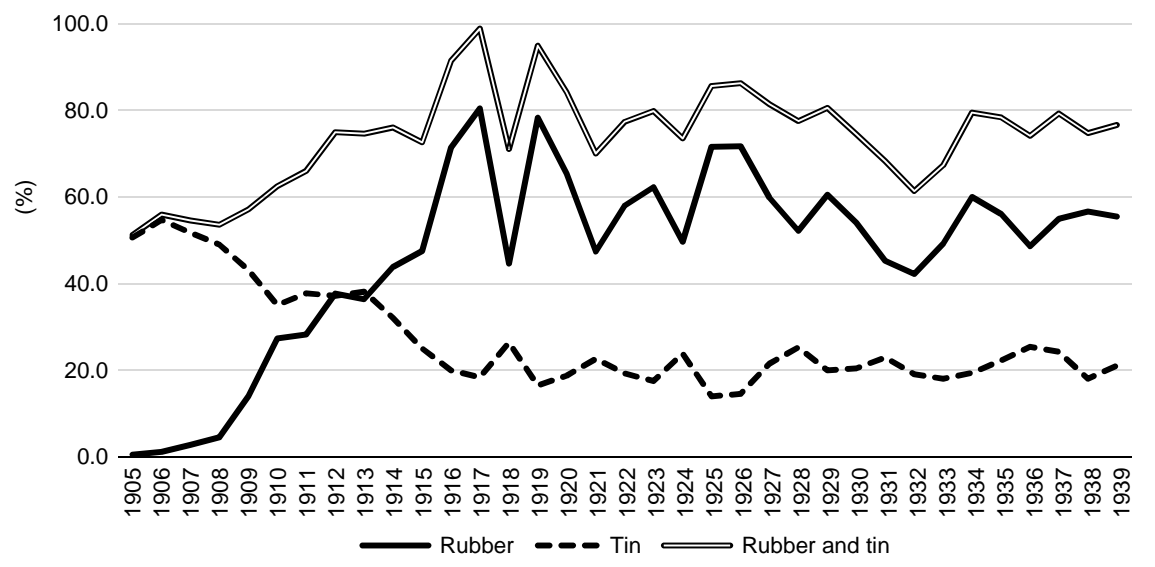

Figure 6.5 Malaya - Share of Tin and Rubber in Total Exports.

Source: Economic History of Malaya. https://www.ehm.my/home (accessed 30 July 2019). 


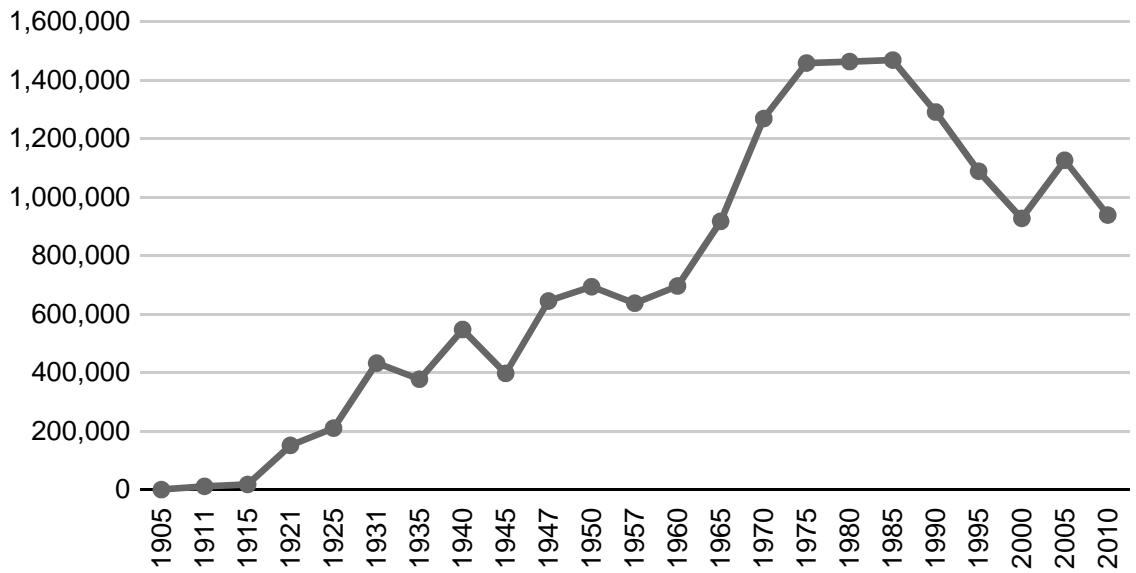

Figure 6.6 Rubber Production, 1905-2010 (tonnes).

Sources: Food and Agriculture Organization of the United Nations; Bruton (1992).The Political Economy of Poverty, Equity and Growth: Sri Lanka and Malaysia. Washington, DC: World Bank; Lim (1967). Economic Development of Modern Malaya. Kuala Lumpur: Oxford University Press.

15

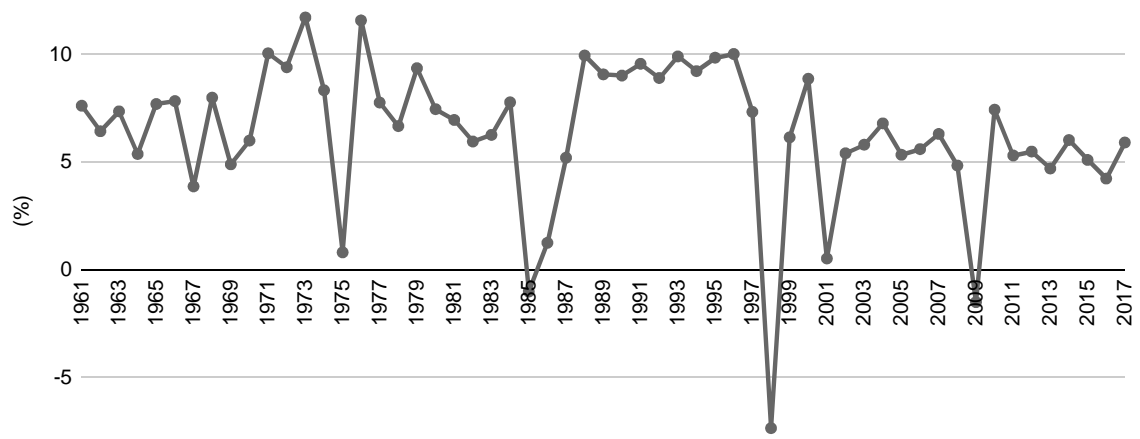

$-10$

Figure 6.7 Annual Real Gross Domestic Product Growth - Malaysia, 1961-2017. Source: World Bank Open Data. https://data.worldbank.org (accessed 30 July 2019).

the promotion and development of the palm oil industry, petroleum and gas, and export-oriented manufacturing.

Historically, oil palms were first introduced into Malaya in the 1870s, but palm oil only became an important commercial crop between 1917 and 1960 (Rasiah, 2006). Palm oil production grew very rapidly starting in the 1970 s partly due to the 


\section{Cassey Lee}

land development schemes implemented by the government (Figure 6.8). Even today, palm oil remains an important export, accounting for 7-9\% of total exports.

Petroleum and gas have been important industries since the 1970s. The early phase of commercial oil exploration was undertaken during 1910-29 in Sarawak, but this was exhausted by 1973 (Adnan, 1982). Major discoveries in 1973 and 1974 off the coasts of Terengganu, Sabah, and Sarawak expanded the industry significantly. Liquefied natural gas became an important industry in the 1980s. The importance of crude oil and liquefied natural gas exports has fluctuated over the years (Figure 6.9). Fuel as a share of exports peaked at $32 \%$ in 1985 and $22 \%$ in 2013. In 2017, fuel as a share of exports was around $15 \%$.

In the post-independence period, the most important structural change has been the rise of the manufacturing sector. Malaysia's export-oriented industrialisation strategy began in the 1960s. As a result, the manufacturing sector as a share of GDP has risen over time from $10 \%$ in 1960 to $31 \%$ in 1999 (Figure 6.10). A rapid expansion in manufacturing's role in the economy can be observed in two periods: 1963-80 and 1987-99.

Foreign direct investment (FDI) has been a significant driver of the rise of manufacturing. The first phase of export-oriented industrialisation was fuelled by FDI from the West. In the second phase, FDI in the late 1980s came primarily from Japan following the Plaza Accord. FDI as a share of GDP rose from $1.3 \%$ in 1987 to $8.7 \%$ in 1992 (Figure 6.11). However, since 1999, manufacturing's relative contribution to the economy has declined and this can also be seen from the trends in the sector's share of total employment (Figure 6.12). The country's

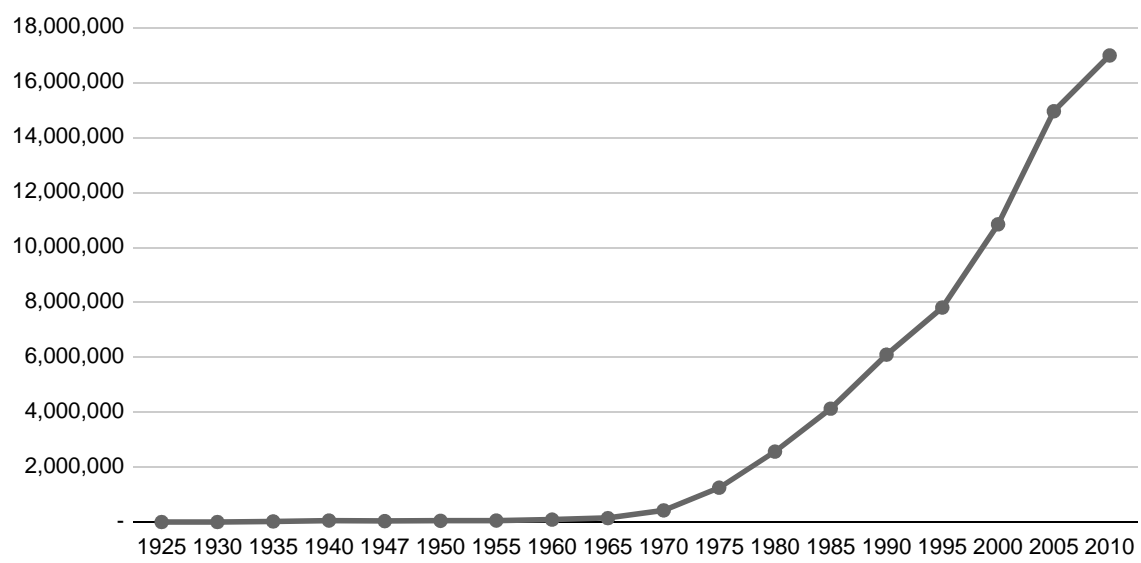

Figure 6.8 Palm Oil Production, 1925-2010 (tonnes).

Sources: Food and Agriculture Organization of the United Kingdom. http://www.fao.org/ statistics/en (accessed 30 July 2019); Lim (1967),Economic Development of Modern Malaya. Kuala Lumpur: Oxford University Press; Malaysian Palm Oil Board. http:// bepi.mpob.gov.my/index.php/en/statistics/production.html (accessed 30 July 2019). 


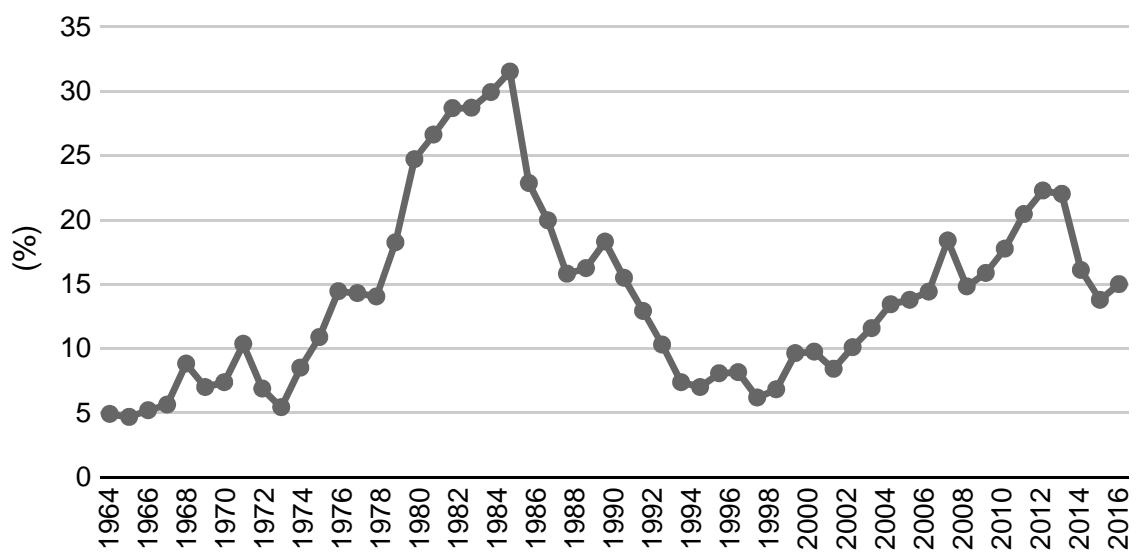

Figure 6.9 Fuel Exports (\% of merchandise exports).

Source: World Bank Open Data. https://data.worldbank.org (accessed 30 July 2019).

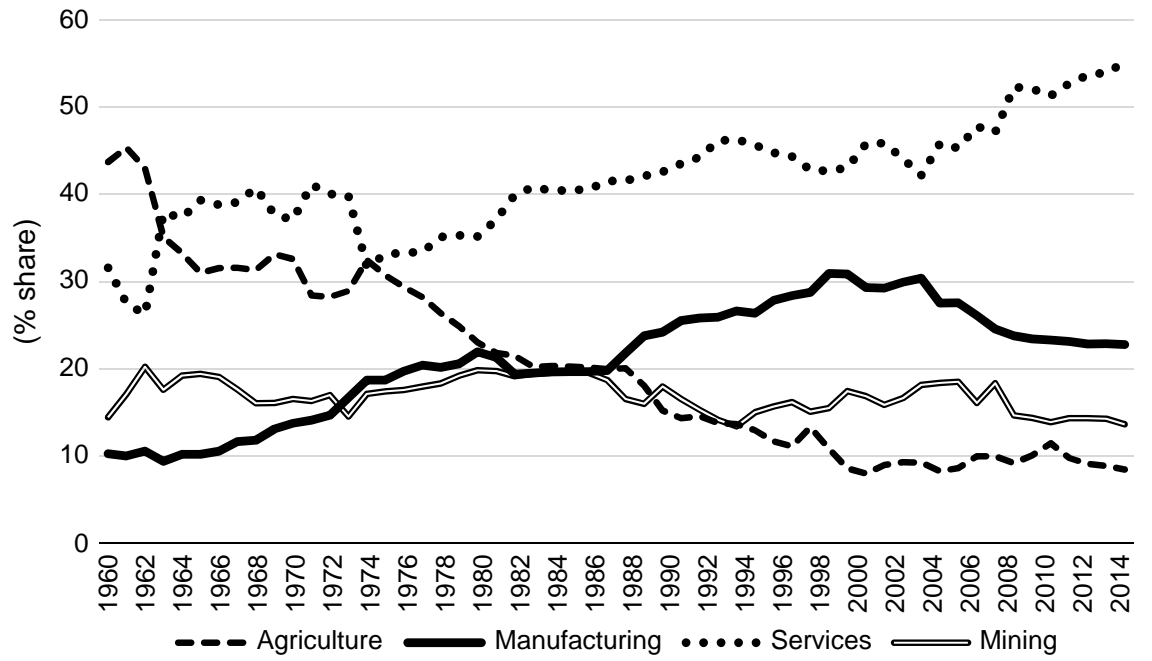

Figure 6.10 Structural Composition of Malaysia's Gross Domestic Product, 1960-2015.

Source: World Bank Open Data. https://data.worldbank.org (accessed 30 July 2019).

export structure has also changed over time (Figure 6.13). At its peak in 1999, the manufacturing sector accounted for some $80 \%$ of the country's total exports (Figure 6.14). However, the sector's share of GDP declined from $30 \%$ in 1999-2004 to about $22 \%$ in 2015. Thus, following a long period of 


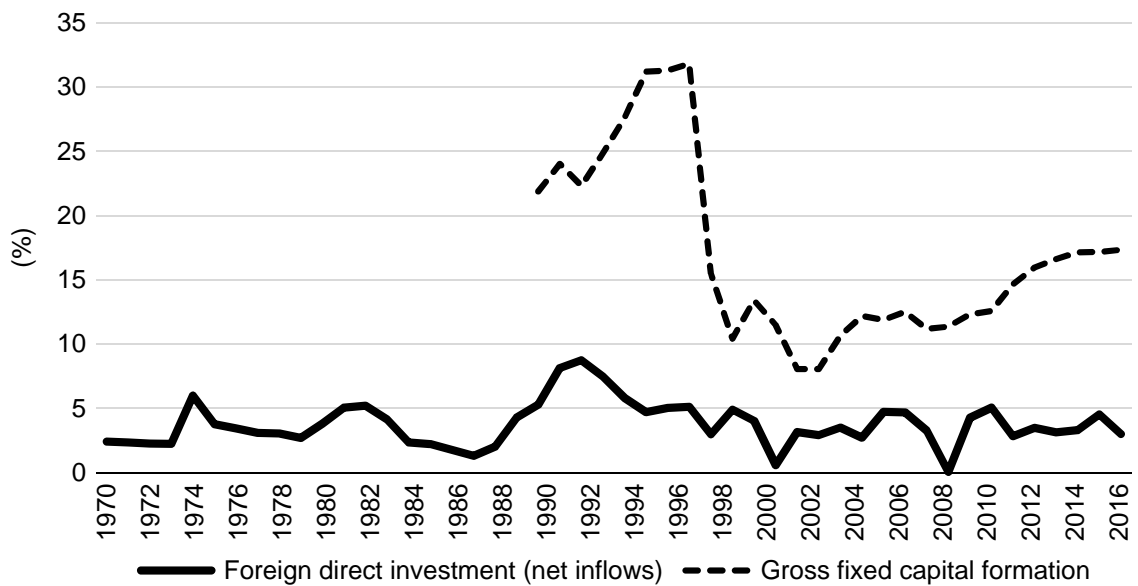

Figure 6.11 Foreign Direct Investment and Capital Formation as a Share of Gross Domestic Product.

Source: World Bank Open Data. https://data.worldbank.org (accessed 30 July 2019).

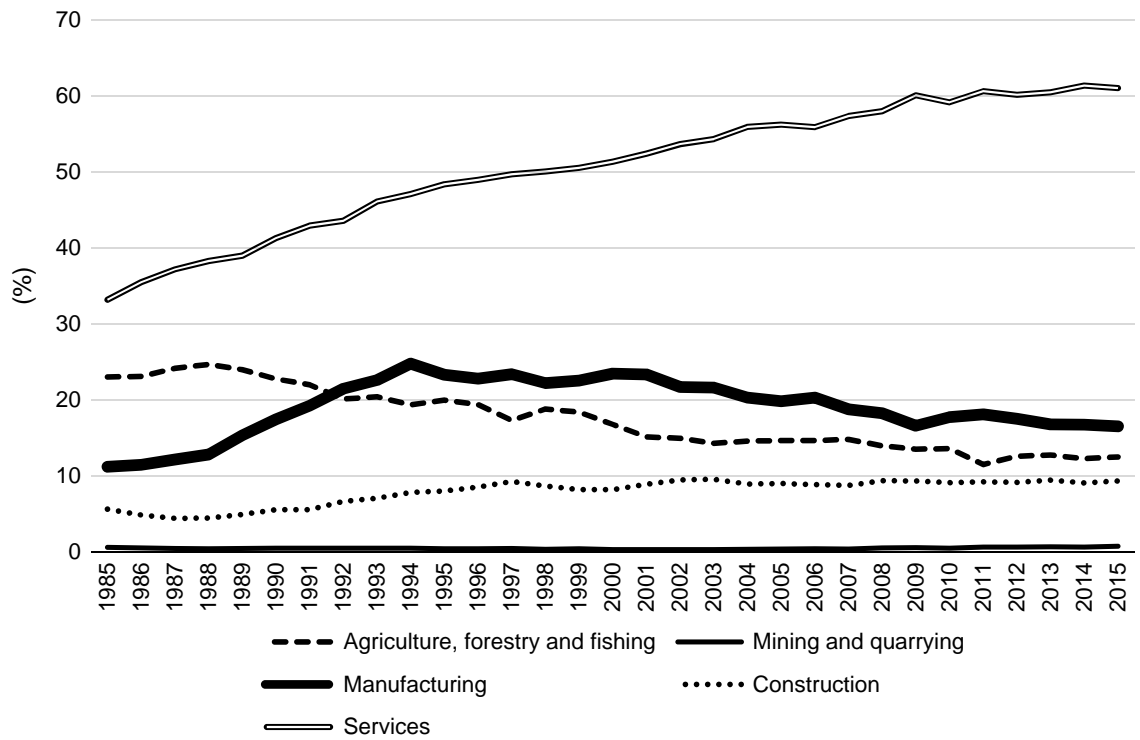

Figure 6.12 Sectoral Composition of Total Employment, 1985-2015.

Source: Department of Statistics. https://www.dosm.gov.my/vl/ (accessed 30 July 2019). 


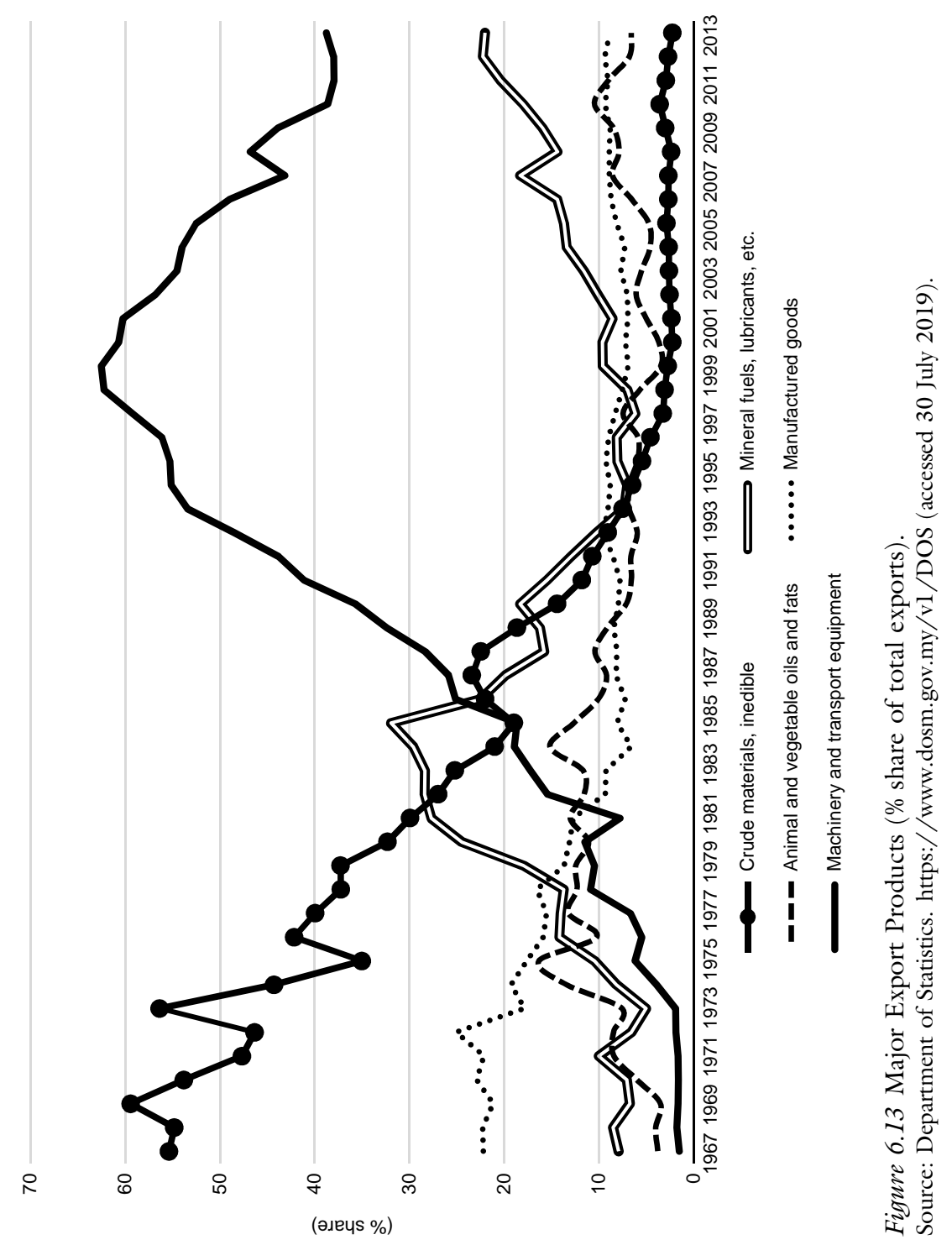




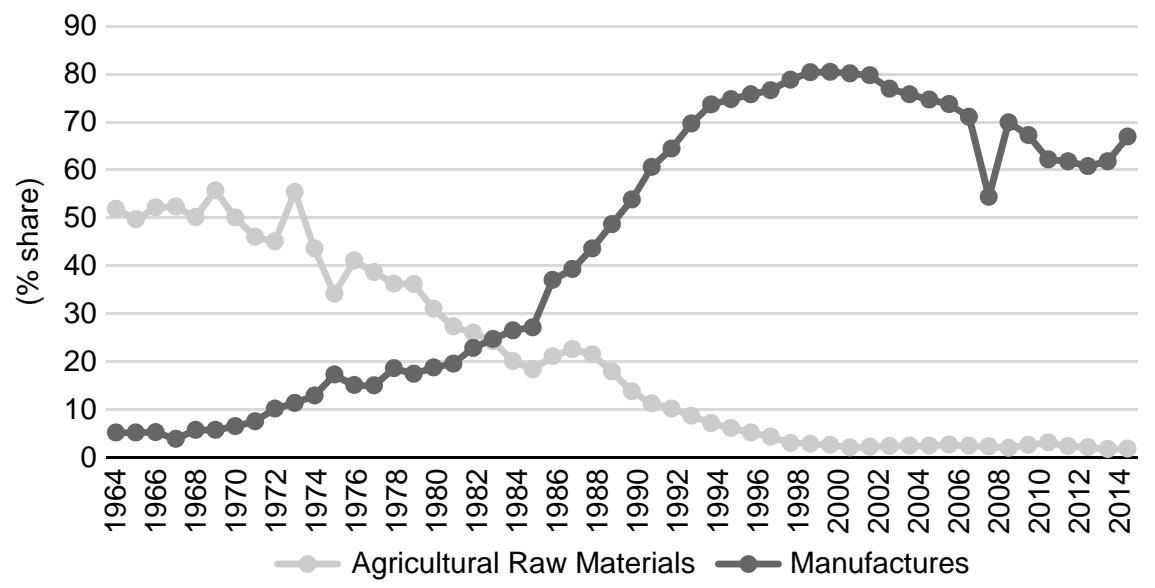

Figure 6.14 Agricultural and Manufactured Exports (\% of total exports). Source: World Bank Open Data. https://data.worldbank.org (accessed 30 July 2019).

industrialisation over a period of 40 years from around 1960 to 2000 , the economy has been deindustrialising for close to 20 years since 1999/2000. This has been accompanied by the rise of the services sector's share of GDP $(55 \%$ in 2015 ) and employment (60\%).

\subsection{Empirical studies on globalisation and economic growth}

A number of time-series econometric studies on globalisation and economic growth in Malaysia have been carried out. In an early study using quarterly time-series data for the period 1970-94, Ahmad and Rashid (1999) found evidence of a stationary long-term relationship amongst exports, imports, and GDP. The study also found a feedback causal relationship between exports and economic growth for both manufacturing and agricultural exports.

Keong, Yusopa, and Khim-Sen (2003) used annual data for the period 1959-2000 to test the export-led growth hypothesis for Malaysia. The authors found that the hypothesis is valid for Malaysia in both the short and long term. The study also found that the growth rate is also positively affected by the growth rate of capital formation and imports.

Sulaiman and Saad (2009) used annual time series data for the period 1960-2005 to verify the positive relationship between exports and economic growth. The study also found a negative relationship between imports and economic growth.

In a more recent study, Makun (2017) used annual data for the period 1980-2013 to show that a positive and significant relationship exists between 
trade openness and growth. Furthermore, the effect of trade openness on growth is strengthened by human capital and good economic policies.

Overall, the empirical evidence on the relationship between exports and economic growth has been fairly robust across the different studies employing timeseries econometrics. There is strong evidence that globalisation has a positive impact on economic growth in both the short and long term.

\section{Impact of globalisation}

Globalisation has impacted the Malaysian economy in many ways and through different mechanisms. This can be examined using different sources of information and data at various levels of aggregation. Section 4.1 discusses the empirical microdata literature on exporting, innovation, and productivity in the Malaysian manufacturing sector. Section 4.2 examines how trade and foreign labour have impacted Malaysia in terms of the country's demography and human capital over time. The impact of globalisation on poverty and inequality in Malaysia is discussed in Section 4.3. The openness of the Malaysian economy has also rendered it vulnerable to external economic shocks. This is discussed in Section 4.4. Finally, the relationship between globalisation and institutions (e.g. corruption) is discussed in Section 4.5.

\subsection{Exporting, innovation, and productivity}

Evidence on the role and impact of globalisation can also be derived from studies using microdata. In an early microdata study on the Malaysian manufacturing sector covering the period 2000-2001, Lee (2004) found that innovation is positively and significantly correlated with foreign participation. However, the same study showed that exporting may have a reverse relationship with innovation. This surprising result has been attributed to sampling limitations.

A study by Noor and Adam (2009), which used microdata from Malaysian manufacturing industries for the period 2000-04, found significant evidence of positive productivity spillovers to local firms in the same industry when foreign shareholding is used to measure foreign presence. Interestingly, the authors did not find any significant difference in labour productivity between wholly foreignowned and locally owned establishments when foreign presence is proxied by employment share. In addition, both majority and minority foreign-owned establishments have significantly lower levels of labour productivity than locally owned establishments in Malaysia.

In a later study on productivity and exporting in the Malaysian manufacturing sector covering the period 1997-2004, Lee (2011a) found that the link between exporting and productivity is a weak. However, the paper presents stronger evidence that exporting is related to innovation.

Innovation by firms in the manufacturing sector can also be driven by their participation in the global economy through knowledge flows. Using firm-level manufacturing data covering the period 2002-04, Lee (2011b) provides some 


\section{Cassey Lee}

evidence that FDI and exporting are related to innovation activities such as training and acquisition of machinery, equipment, and software. However, the study also found that the links between innovative firms in Malaysia and other firms abroad in terms of cooperative activities are relatively weak.

Dogan, Nyen, and Yap. (2011) used a manufacturing micro panel data to examine the differences in productivity between exporters and non-exporters. Their study showed that exporters are more productive than are domesticoriented establishments. Entrants to export markets were more productive than both the surviving domestic-oriented establishments (non-exporters) and, even more telling, surviving exporters. On the other hand, exiters from the export markets or 'export failures' were less productive than continuing exporters. Churning was also found to contribute to productivity growth in manufacturing due to entrants having higher productivity than exiters. In addition, the churning of exporters made larger contributions to productivity growth than churning amongst domestic-oriented firms.

Lee (2012) studied the dynamics of productivity and innovation using panel firm-level data from the manufacturing sector covering the years 2002 and 2006. The study provides some evidence for the existence of strong productivity premiums for continuing exporters (compared to non-exporters) and relatively weak productivity premiums for new exporters. There is also evidence of causality from exporting to innovation that supports the learning-by-exporting hypothesis in the case of Malaysia. It was also found that continuous exporters enjoy significant exporting premiums in terms of scale of production.

Another study by Lee (2013) examined the impact of globalisation on wage inequality at the firm level. The study used microdata collected by the Malaysian government covering the years 2002 and 2006 and the World Bank (covering the year 2006). The study found that there is a positive but weak relationship between average wage levels and exporting. There is also a positive relationship between trade liberalisation and wages, although this relationship is stronger for skilled workers. The employment of foreign workers also has a depressive effect on average wage levels for skilled workers.

Lee (2014) used manufacturing data for 2002 and 2006 to study the relationship between exporting and productivity across different firm sizes. The study affirmed the positive relationship between productivity and exporting. However, for larger firms, the productivity gap between exporters and nonexporters became less important, suggesting that the selection process for exporting is binding only for small firms.

Dogan, Nyen, and Yap (2017) used manufacturing microdata from 2000 to 2005 to analyse FDI spillover effects empirically. Their empirical findings are not very encouraging - horizontal spillovers from FDI are weak. In addition, backward and forward spillovers are found to be negative.

In a recent study, Chuah, Loayza, and Minh (2018) used microdata from three manufacturing censuses $(2000,2005$, and 2010$)$ to study the intra-sectoral reallocation of resources. In terms of globalisation, the authors found that export-oriented industries are generally more efficient at resource allocation. 
These industries include the textile, wood products, and electrical and electronics industries. The authors also found that the productivity gap between Malaysia and the United States (US) has widened over time.

In summary, microdata studies on manufacturing do suggest that exporting is associated with higher productivity. The contribution of churning amongst exporting firms shows how such processes can contribute to economic growth. These findings are generally consistent with the theoretical and empirical literature in heterogeneous firms and trade (Melitz, 2003). There is also evidence supporting a positive relationship between innovation and exporting. These studies indicate that globalisation in the form of exporting is beneficial to firms in the manufacturing sector. However, there are weaknesses in the current state of export participation, including limited spillover effects and constraints on knowledge flows between subsidiaries based in Malaysia and their headquarters in more developed countries. Finally, even though there is a positive relationship between productivity and foreign ownership, this may not necessarily translate into a positive link between wages and exporting. This is due to excessive reliance on foreign labour with low skills and low human capital. This issue is explored further in the next section.

\subsection{Trade, foreign labour, and buman capital}

Globalisation, in the form of trade and migration, has had a significant and longterm impact on Malaysia. In the pre-independence period under British colonial rule, the development of labour-intensive and trade-oriented industries such as tin and rubber necessitated the use of foreign labour. Between 1850 and 1930, the development of the tin industry brought about a massive migration of foreign workers from China into the tin mining areas in Malaya. Similarly, the advent and rapid growth of the rubber industry during 1911-31 saw the migration of workers primarily from South India.

The impact of migration went beyond the development of export-oriented primary commodities industries. The most important effect of the inflows of migrant workers in the 1850 s to 1930 s was the formation of a multi-ethnic society in Malaysia. While some migrant communities can be traced as far back as the fifteenth century, these earlier migrant communities were relatively small. The later waves of migrants into the tin and rubber industries were significantly larger to the extent that they subsequently altered the demographic composition of Malaysia. By 1947, the Chinese population in Malaya accounted for $38.4 \%$ of the total population (Table 6.1). The Indian community's share of total population peaked at $15 \%$ in 1921 . Most of these migrant workers eventually became citizens of Malaysia. As a result of lower fertility rates amongst the Chinese and Indian communities in Malaysia, their population shares have declined over time. Despite this, Malaysia remains a multi-ethnic society. This has had important implications on the political economy of resource distribution in the country.

During the colonial period, one of the contentious elements in the Malayan Union (1846-1948) was the granting of citizenship and equal rights to migrant 
Table 6.1 Census Population by Ethnic Group, Peninsular Malaysia, 1911-2010

\begin{tabular}{|c|c|c|c|c|c|}
\hline \multicolumn{6}{|c|}{ Population (number) } \\
\hline Year & Malays/Bumiputra & Chinese & Indians & Others & Total \\
\hline 1911 & $1,368,954$ & 693,228 & 239,169 & 37,700 & $2,339,051$ \\
\hline 1921 & $1,568,588$ & 855,863 & 439,172 & 43,068 & $2,906,691$ \\
\hline 1931 & $1,863,872$ & $1,284,888$ & 572,613 & 66,385 & $3,787,758$ \\
\hline 1947 & $2,427,834$ & $1,884,534$ & 530,638 & 65,080 & $4,908,086$ \\
\hline 1957 & $3,125,474$ & $2,333,756$ & 696,186 & 123,342 & $6,278,758$ \\
\hline 1970 & $4,663,284$ & $3,117,896$ & 933,250 & 66,298 & $8,780,728$ \\
\hline 1980 & $6,315,572$ & $3,865,431$ & $1,171,135$ & 74,475 & $11,426,613$ \\
\hline 1991 & $8,433,826$ & $4,250,969$ & $1,380,048$ & 410,544 & $14,475,387$ \\
\hline 2000 & $11,135,694$ & $4,883,079$ & $1,666,048$ & 147,749 & $17,832,570$ \\
\hline 2010 & $13,735,752$ & $5,509,302$ & $1,892,322$ & 130,205 & $21,267,581$ \\
\hline \multicolumn{6}{|c|}{ Population share (\%) } \\
\hline Year & Malays/Bumiputra & Chinese & Indians & Others & Total \\
\hline 1911 & 58.5 & 29.6 & 10.2 & 1.6 & 100.0 \\
\hline 1921 & 54.0 & 29.4 & 15.1 & 1.5 & 100.0 \\
\hline 1931 & 49.2 & 33.9 & 15.1 & 1.8 & 100.0 \\
\hline 1947 & 49.5 & 38.4 & 10.8 & 1.3 & 100.0 \\
\hline 1957 & 49.8 & 37.2 & 11.1 & 2.0 & 100.0 \\
\hline 1970 & 53.1 & 35.5 & 10.6 & 0.8 & 100.0 \\
\hline 1980 & 55.3 & 33.8 & 10.2 & 0.7 & 100.0 \\
\hline 1991 & 58.3 & 29.4 & 9.5 & 2.8 & 100.0 \\
\hline 2000 & 62.4 & 27.4 & 9.3 & 0.8 & 100.0 \\
\hline 2010 & 64.6 & 25.9 & 8.9 & 0.6 & 100.0 \\
\hline
\end{tabular}

Source: Economic History of Malaya. https://www.ehm.my/home (accessed 30 July 2019).

communities. In the aftermath of the nation's independence, children of migrants born in Malaya/Malaysia were automatically granted citizenship (the $j u s$ soli principle). However, the racial riots on 13 May 1969 proved to be a turning point in Malaysia. Thereafter, affirmative action policies were introduced to correct the economic imbalance across the different ethnic groups in Malaysia. The New Economic Policy (NEP) was introduced in 1970 both to eradicate poverty and to redress inter-ethnic economic imbalance.

The inter-ethnic economic imbalance is related to economic globalisation. The inflow of Chinese migrants in the late nineteenth century was mainly concentrated in modern sectors located in the more developed and urbanised states in Peninsular Malaysia. The Malay population was primarily agrarian and resided in less developed areas and states.

Thus, Malaysia's engagement in economic globalisation has had an impact on urbanisation and the spatial concentration of economic activities. In terms of urbanisation, the development of the tin industry during 1850-1930 brought about a massive migration of Chinese workers to the tin mining areas in three states, namely, Perak, Selangor, and Negeri Sembilan (Sidhu and Jones, 1981). The five largest cities during 1911-31 were Georgetown (Penang), Kuala Lumpur (Selangor), Ipoh (Perak), Melaka, and Taiping (Perak) (see Figure 6.15). With the 


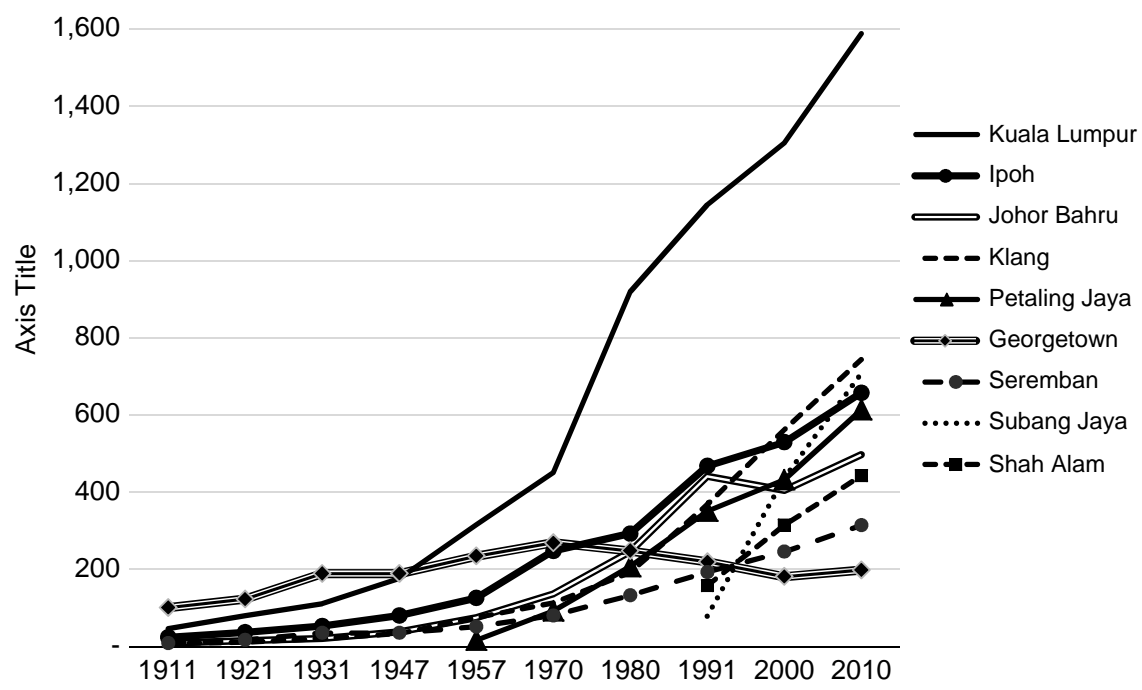

Figure 6.15 Size of Major Cities, 1911-2010 ('000 people).

Sources: Lim (1978), The Evolution of the Urban System in Malaysia. Kuala Lumpur: University of Malaya Press; Saw (2015), The Population of Malaysia, Second Edition. Singapore: Institute of Southeast Asian Studies; Department of Statistics, 2010 Population and Housing Census of Malaysia. https://www.dosm.gov.my/vl/ (accessed 30 July 2019).

exception of Melaka, these cities were mainly associated with tin mining activities. With the decline in mining, a few cities that relied on mining such as Georgetown (which was involved in the trading and shipping of tin) and Taiping declined in importance (Figure 6.16). For other cities, such as Seremban and Kuala Lumpur, the advent and rapid growth of the rubber industry (during the periods 1911-31 and 1947-80) and later palm oil likely mitigated the effects of the decline in the tin mining industry.

The rise of manufacturing since the 1960s also contributed to the growth of old cities (Ipoh and Johor Bahru) and the development of new ones such as Petaling Jaya and later, Shah Alam and Subang Jaya. The growth of these cities entailed inter-state migration that began to skew the population distribution across the Malaysian states (Table 6.2). The share of total population increased significantly in states with export-oriented manufacturing such as the state of Selangor.

Initially, the development of FDI-driven and export-oriented manufacturing did not entail the extensive use of foreign workers. However, by the early 1990s, the country began to experience labour shortages. This led to a rapid growth in the number of foreign workers in manufacturing, agriculture, and services for the 
8

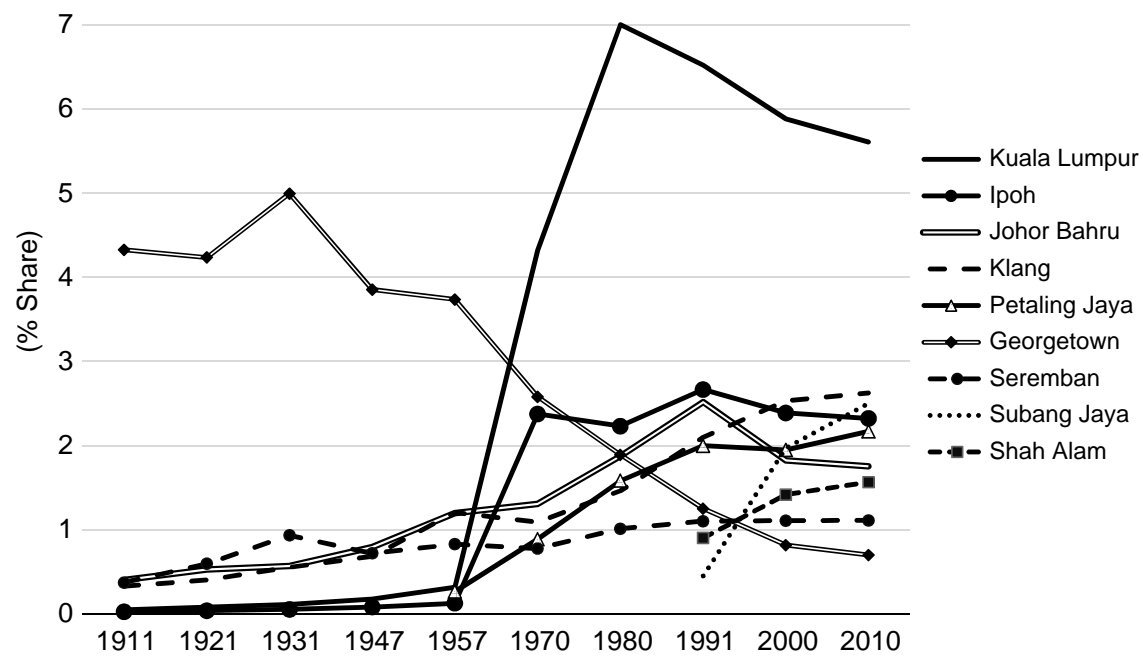

Figure 6.16 Major Cities' Share of Total Population, 1911-2010.

Sources: Lim (1978), The Evolution of the Urban System in Malaysia. Kuala Lumpur: University of Malaya Press; Saw (2015), The Population of Malaysia, Second Edition. Singapore: Institute of Southeast Asian Studies; Department of Statistics, 2010 Population and Housing Census of Malaysia. https://www.dosm.gov.my/vl/ (accessed 30 July 2019).

next 20 years. The dependence on foreign workers has increased across all states since the 1980s (Figure 6.17). Looking at the trends in foreign workers' share of total employment since the early 1980s, it can be seen that the share of foreign labour increased rapidly during two periods in particular: 1993-96, and 2009-13. The degree of dependence on foreign labour varied from state to state. The state of Sabah is especially dependent on foreign labour. Foreign workers account for some $40 \%$ of total employment in the state. Other states with significant dependence on foreign workers include Selangor (15\%) and Kuala Lumpur (13\%).

There are currently no data on foreign workers by sector in different states, but given differences in economic structure, foreign workers are likely concentrated in two sectors: (i) agriculture in Sabah and Sarawak; and (ii) manufacturing and services in Johor, Selangor, and KL. Agriculture and manufacturing are the two key sectors employing foreign labour (Figure 6.18).

One key concern with respect to the country's dependence on foreign workers is the relatively low human capital and skills associated with foreign workers compared to local workers. In 2015 , only $5.7 \%$ of foreign workers had tertiary degrees whereas the corresponding figure for domestic workers exceeded $20 \%$ (Table 6.3). 


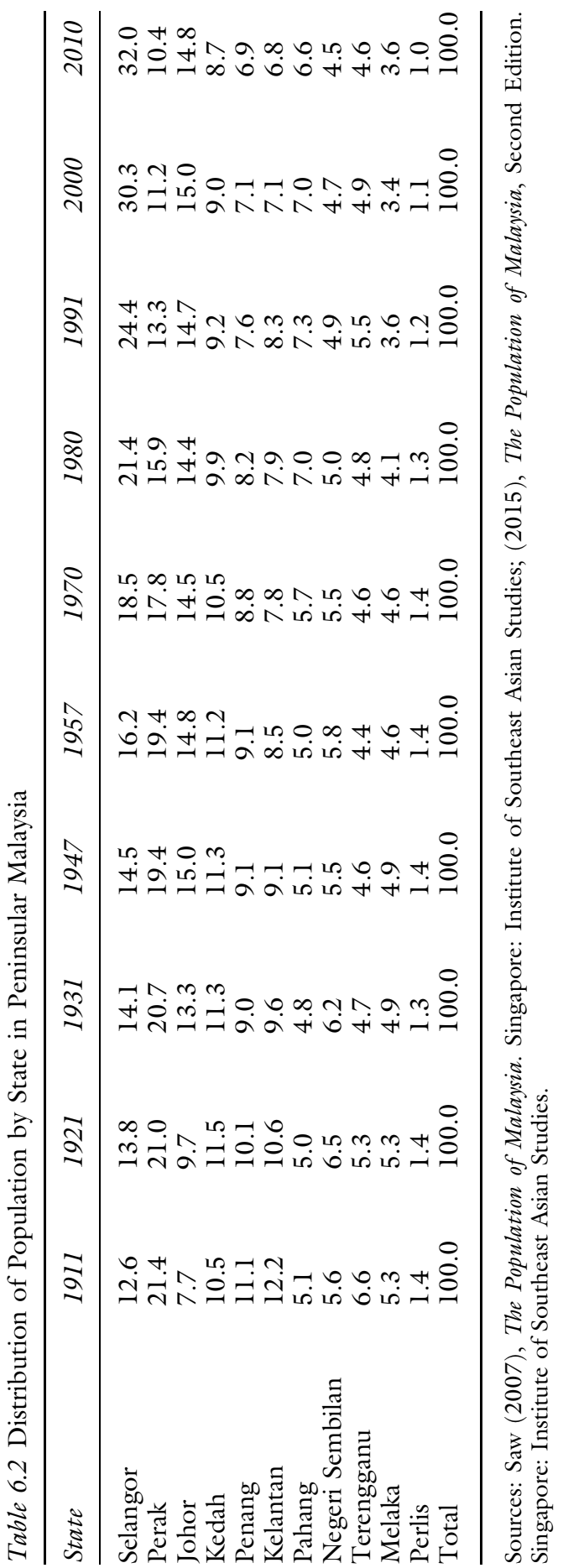




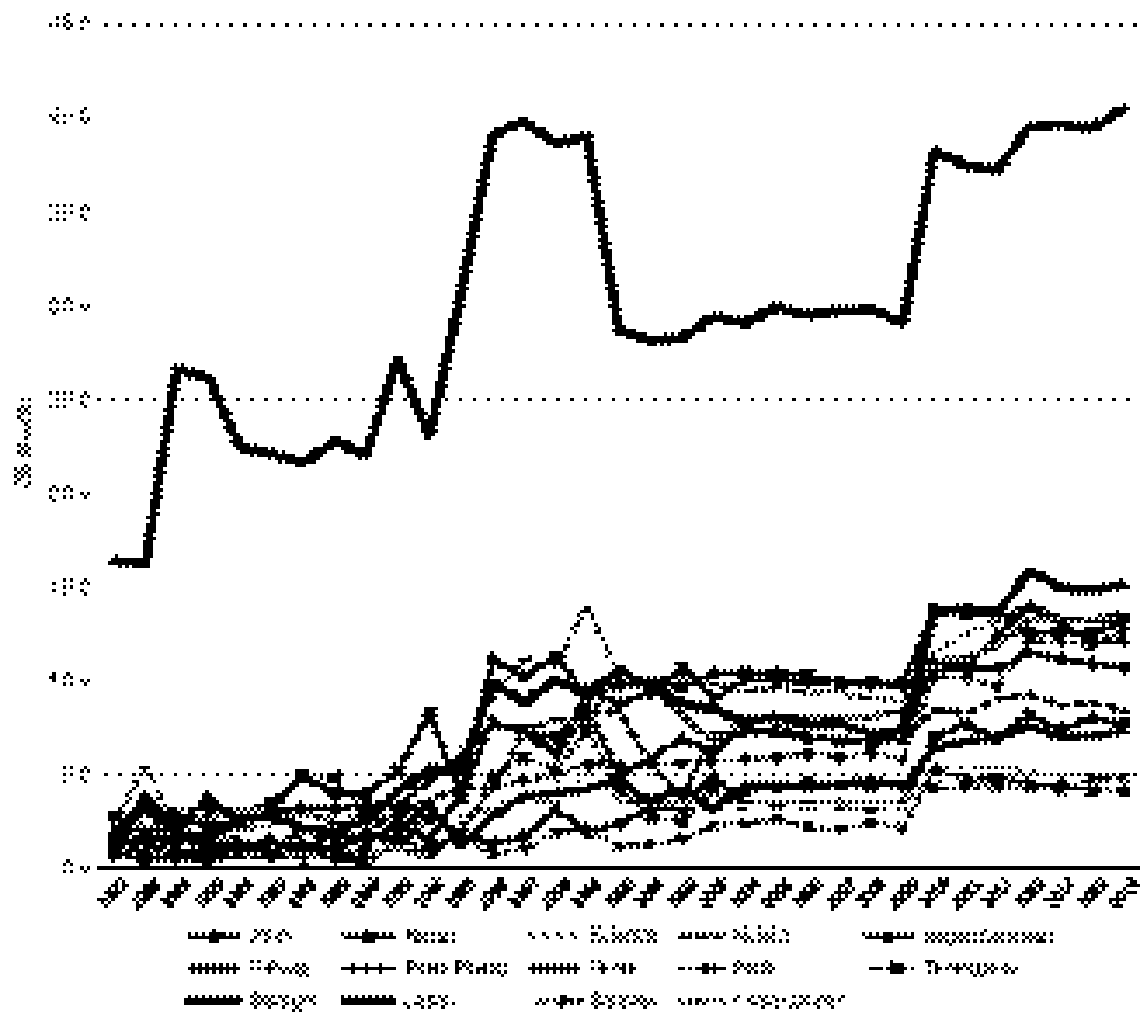

Figure 6.17 Foreign Workers' Share of Total Employment, 1982-2016.

Source: Department of Statistics, https://www.dosm.gov.my/vl/DOS (accessed 30 July 2019).

The World Bank (2012) estimated that in 2014 about $44 \%$ of foreign workers in Malaysia were employed in low-skilled elementary occupations. Only $5 \%$ of foreign workers in Malaysia have high-skilled jobs. Furthermore, sectors likely matter. Foreign workers in agriculture and construction may have lower human capital and skills than foreign workers in manufacturing and services. The proportion of foreign workers with no formal education (noedupct) or primary education (primarypct) is particularly high in states with large agriculture sectors such as Sabah and Sarawak (Figure 6.19).

Relatively cheap and low-skilled foreign labour helped sustain the country's manufacturing competitiveness in the 1990s; however, this later became an obstacle to efforts to upgrade the manufacturing and other economic sectors. The country's heavy dependence on low-skilled foreign workers has adversely affected productivity growth in all sectors in the economy. Access to cheap foreign labour could have disincentivised employers from upgrading their production technology (more capital intensive) and investing in human capital 


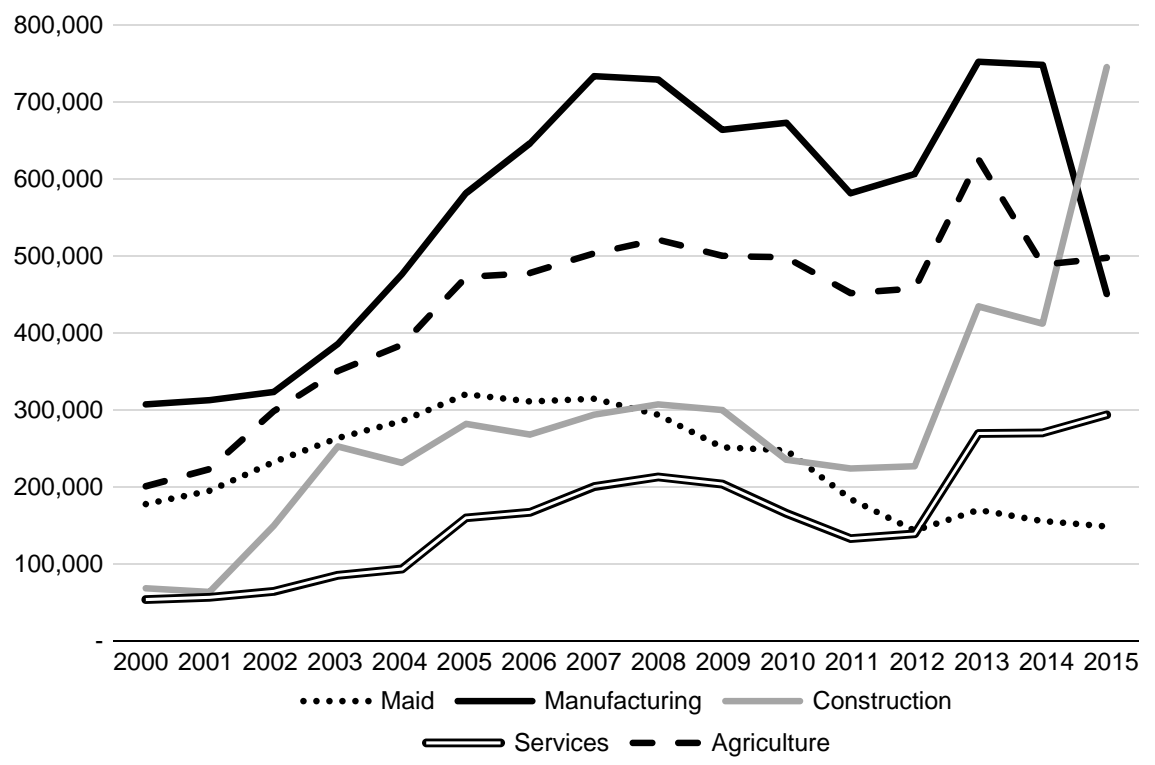

Figure 6.18 Number of Foreign Workers in Malaysia by Sector, 2000-15.

Source: Department of Statistics, https://www.dosm.gov.my/vl/DOS (accessed 30 July 2019).

Table 6.3 Labour Force by Educational Attainment, 2015

\begin{tabular}{lllllll}
\hline & Malay & Chinese & $\begin{array}{l}\text { India- } \\
\text { ns }\end{array}$ & Others & Foreigners & Total \\
\hline No formal education & 169.6 & 19.2 & 15.5 & 6.1 & 236.0 & 446.3 \\
$\%$ & 2.1 & 0.6 & 1.7 & 6.4 & 10.9 & 3.1 \\
Primary & 796.2 & 322.0 & 102.6 & 22.0 & 986.8 & $2,229.6$ \\
$\%$ & 9.7 & 10.2 & 11.3 & 23.3 & 45.5 & 15.4 \\
Secondary & $4,584.2$ & $1,856.1$ & 526.3 & 46.9 & 823.1 & $7,836.6$ \\
$\%$ & 56.0 & 58.9 & 58.0 & 49.7 & 37.9 & 54.0 \\
Tertiary & $2,642.4$ & 956.7 & 263.3 & 19.4 & 123.5 & $4,005.4$ \\
$\%$ & 32.3 & 30.3 & 29.0 & 20.6 & 5.7 & 27.6 \\
Total & $8,192.4$ & $3,154.0$ & 907.7 & 94.5 & $2,169.4$ & $14,518.0$ \\
& 100.0 & 100.0 & 100.0 & 100.0 & 100.0 & 100.00 \\
\hline
\end{tabular}

Source: Department of Statistics. https://www.dosm.gov.my/vl/DOS (accessed 30 July 2019)

development. There is some evidence that the use of foreign labour could have weakened agglomeration economies related to human capital (Lee, 2018). Upgrading the country's manufacturing sector requires workers that are productive, innovative, and well-paid (World Bank, 2012). 
150 Cassey Lee

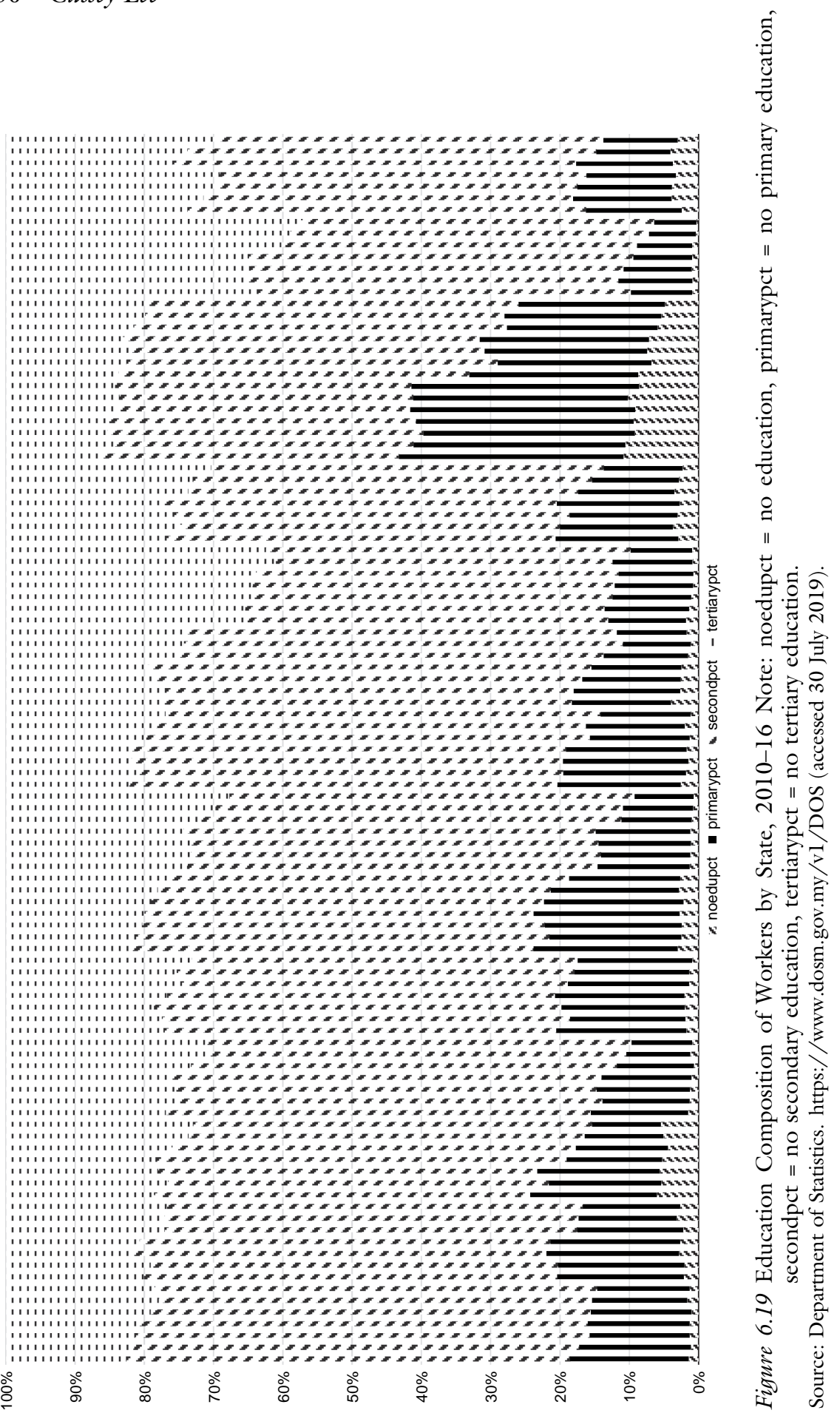




\subsection{Poverty and inequality}

Malaysia has made significant progress towards eradicating poverty since the 1970s. In 1970, close to $50 \%$ of the country's population were living below the poverty line. By 1997, the incidence of poverty had declined to about $11 \%$. Even though the government implemented rural development programmes (such as the Federal Land Development Authority scheme) to eradicate poverty, the most important factor has been identified as the absorption of rural educated workers into higher income occupations in the industrial and services sectors (Ragayah, 2011). Thus, insofar as the country's manufacturing sector is export-oriented, globalisation has had a positive and indirect impact on the decline in the incidence of poverty in Malaysia.

Inequality in Malaysia as measured by the Gini ratio has declined over time since the 1960s (Figure 6.20). Significant reductions were achieved in the second half of the 1970s and remained relatively stable thereafter until further declines in the 2000s. A number of factors were identified, including improved salaries at the lowest levels in the public sector, a tight labour market, and income transfers to rural households (Ragayah, 2011). These last two factors are indirectly related to globalisation through employment and the incomegeneration effects of the export-oriented manufacturing sector. Figure 6.21

Despite the improvements in inequality, there is growing concern that the country's addiction to cheap foreign labour could have suppressed the wages of lower skilled workers in the labor market. A consequence of this could be worsening wage inequality. A few studies have examined these issues. Athukorala and Devadason (2012) provided industry-level evidence of the negative impact

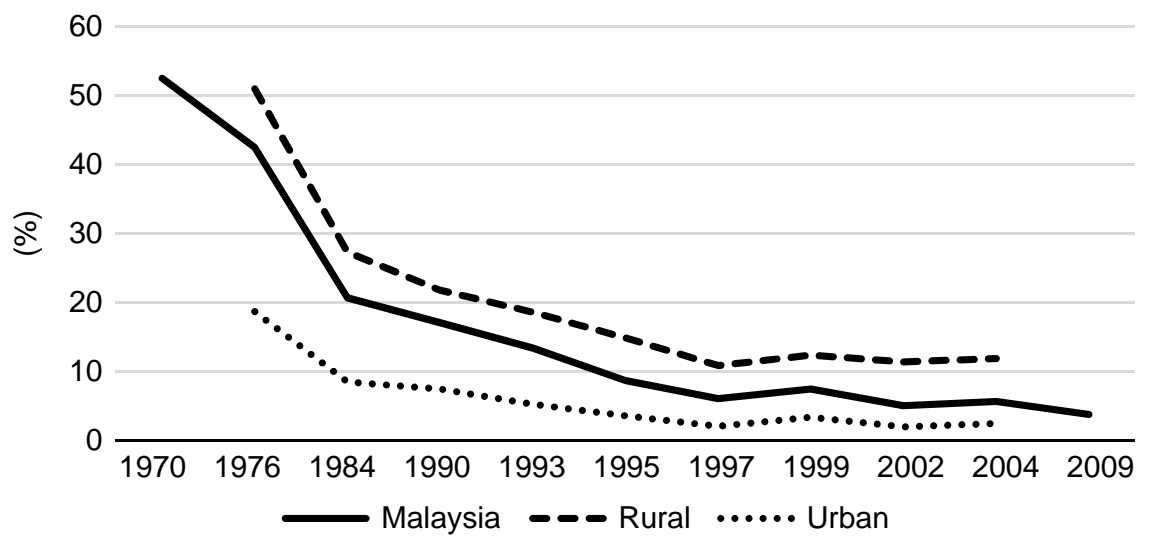

Figure 6.20 Incidence of Poverty in Malaysia, 1970-2009.

Sources: Ragayah (2011), 'Poverty and Income Distribution', in R. Rasiah (ed.) Malaysian Economy. New York: Oxford University Press; (2012), 'Poverty Eradication and Income Distribution', in H. Hill, T.S. Yean, and R.M. Zin (eds.) Malaysia's Development Challenges. London: Routledge. 
0.6

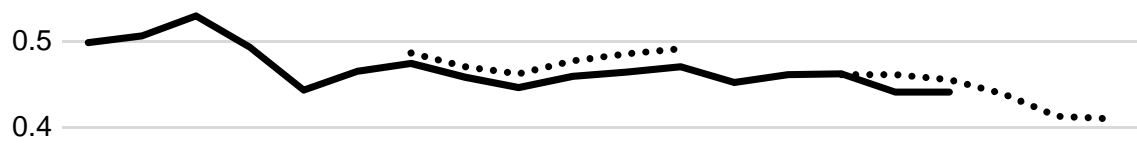

0.3

0.2

0.1

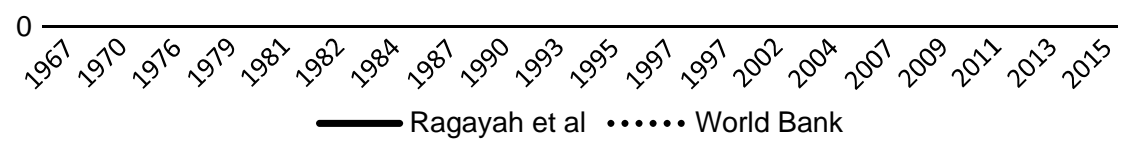

Figure 6.21 Gini Index Estimates.

Sources: Ragayah (2011), 'Poverty and Income Distribution', in R. Rasiah (ed.) Malaysian Economy. New York: Oxford University Press; (2012), 'Poverty Eradication and Income Distribution', in H. Hill, T.S. Yean, and R.M. Zin (eds.) Malaysia's Development Challenges. London: Routledge; World Bank Open Data. https://data.worldbank.org (accessed 30 July 2019).

of foreign workers on the wages of unskilled workers. This is borne out by the changes in average wage levels across occupational categories in the manufacturing sector during 2000-05.

There is also evidence that average wage levels have risen faster at the managerial, technical, and supervisory levels than for clerical, general, and production workers (Table 6Al). A more qualitative analysis was undertaken by Mohamad (2010) who argued that wage inequality worsened during 1995-2007 and that this might be due to industry-level effects and job characteristics. In another study, Said and Hamid (2011) argued that micro-level evidence based on household surveys points to decreasing demand for professional workers (rather than technical workers) due to changes in technology. All of these studies could also be capturing the effects of structural change, that is, deindustrialisation and the increasing prominence of the services sector. More recent data suggest that export-oriented manufacturing may be a less important source of job creation (Figure 6.22).

Finally, an important issue related to inequality in Malaysia is the inter-ethnic income and wealth distribution. Malaysia became a multi-ethnic society through the inflows of migrants into the tin and rubber industries in the late 19th to the early 20th centuries. In 1969, communal tensions following the general elections resulted in racial riots. 


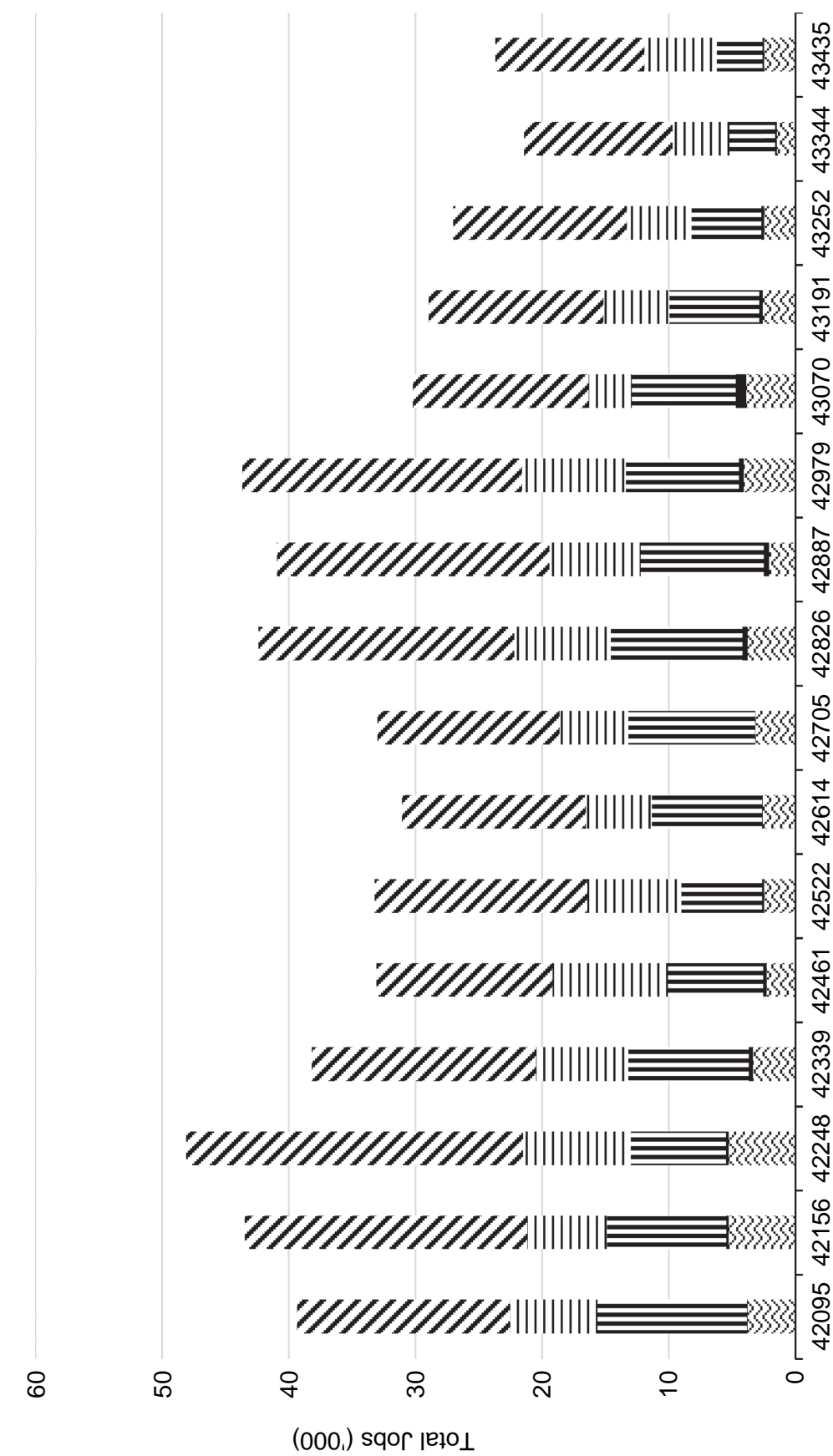




\section{Cassey Lee}

Table 6.4 Ownership of Share Capital in Listed Companies (\%)

\begin{tabular}{lllll}
\hline Group & 1970 & 1985 & 1990 & 2004 \\
\hline Bumiputra & 2.4 & 19.1 & 19.3 & 18.9 \\
Chinese & 27.2 & 33.4 & 45.5 & 39.0 \\
Indians & 1.1 & 1.2 & 1.0 & 1.2 \\
Nominee companies & 6.0 & 7.2 & 8.5 & 8.0 \\
Foreigners & 63.4 & 26.0 & 25.4 & 32.5 \\
\hline
\end{tabular}

Source: Table 4.5 in Leete (2007), Malaysia: From Kampung to Twin Towers. Kuala Lumpur: Oxford Fajar.

The policy response to the riots was the NEP, a long-term strategic policy covering the period 1970-90 and aimed at addressing the root causes of the riots, namely, poverty and inequality. The two goals of the NEP were the eradication of poverty and achieving a more equitable inter-ethnic distribution of income and wealth. The policies for the NEP was subsequently extended under the New Development Policy (1991-2000) and the National Vision Policy (2001-10). In 2010, the New Economic Model covering the period 2011-20 was launched. The orientation of the New Economic Model differed from previous policies in that it attempted to depart from an affirmative action orientation to a more needs-based approach. However, this shift was not very successfully implemented due to concerns from the Bumiputra community regarding the erosion of their rights and special standing.

Several aspects of these NEP-type policies have implications for the country's engagement in globalisation. A key aspect of the implementation of NEP-type policies is the trusteeship model in which state-owned enterprises, government investment corporations, and government-linked corporations hold equity in large companies in key sectors on behalf of the Bumiputra community. These sectors include banking and transport. This strategy was aimed at ensuring that the Bumiputra community owned at least 30\% equity in the modern sector (services and manufacturing). Another important aspect is public procurement in which some preferences were given to Bumiputra-owned companies. This was meant to support and nurture Bumiputra entrepreneurs.

More than 50 years after its implementation, the extent of corporate equity remains controversial. Though official data indicated that Bumiputra ownership in listed companies reached only $18.9 \%$ in 2004 , a study undertaken by the Centre for Public Policy Studies and Asian Strategy and Leadership Institute suggest that the figure could be as high as $45 \%$ in 2005 . In a more recent study, Gomez et al. (2017) estimated that the government's share in the companies listed on the Bursa Malaysia increased from $43.7 \%$ in 2011 to $47.1 \%$ in 2015. Much of the government-owned equity in the corporate sector is in the services sector. Menon and $\mathrm{Ng}$ (2017) have argued that state-owned enterprises or government-linked corporations crowded out private investment in 2007-11. 
There are two important implications of government ownership and control in the services sector. The increasing importance of services in the Malaysian economy implies that the growth of the Malaysian economy is likely to be increasingly driven by productivity in the services sector. Furthermore, there are positive linkages between manufacturing productivity and services inputs (Lee, 2019). If productivity in the services sector is adversely affected by government ownership, this could have negative implications for the future growth of the Malaysian economy.

The significant presence of government ownership in the services sector and affirmative action in government procurement policies could be obstacles to the country's participation in the next generation of trade agreements. This is already an issue in Malaysia's guarded participation in recent trade agreements such as the Comprehensive and Progressive Agreement for Trans-Pacific Partnership. If Malaysia fails to liberalise its trade regime further, including its services sector, this could limit the country's ability to deepen its participation in the global value chain in manufacturing and services.

\subsection{Openness and economic stability}

The openness of the Malaysian economy has made it vulnerable to global economic shocks. This is one of the risks of economic globalisation. Since the country's independence in 1957, there have been four major global economic shocks that have had significant impacts on the Malaysian economy. These include (i) the Organization of Petroleum Producing Countries (OPEC) oil crisis (1973-74), (ii) the commodity crisis (1985-86), (iii) the Asian financial crisis (1997-98), and (iv) the global financial crisis (2008-09)

The impact of each of these shocks is summarised in Figure 6.23 and Table 6.5. The severity of the impact of each of these global economic shocks has varied. This is not surprising as the nature and sources of each of these shocks also differed.

The first shock, the OPEC oil crisis (1973-1974), was triggered by the actions of OPEC member countries. The oil embargo imposed by OPEC on the US and its allies essentially caused a severe oil shortage and a sharp increase in oil prices. This supply-side shock severely affected Malaysia, which had not yet fully developed its oil and gas sector.

The second shock, the commodity crisis (1984-85), was brought about by the high interest rate policy in the US in the early 1980s that weakened demand for primary commodities. This significantly affected Malaysia, which by this time had become a major exporter of both palm oil and, to a lesser extent, rubber and tin. The severity of this crisis was greater as it was more prolonged partly due to the country's inability to implement effective counter-cyclical policies because of fiscal constraints faced by the Malaysian government (Athukorala, 2010)."

The third shock was the Asian financial crisis (1997-98), which was triggered by Thailand's decision to devalue its currency following the Government of Thailand's decision not to peg the baht to the US dollar. This action unnerved 


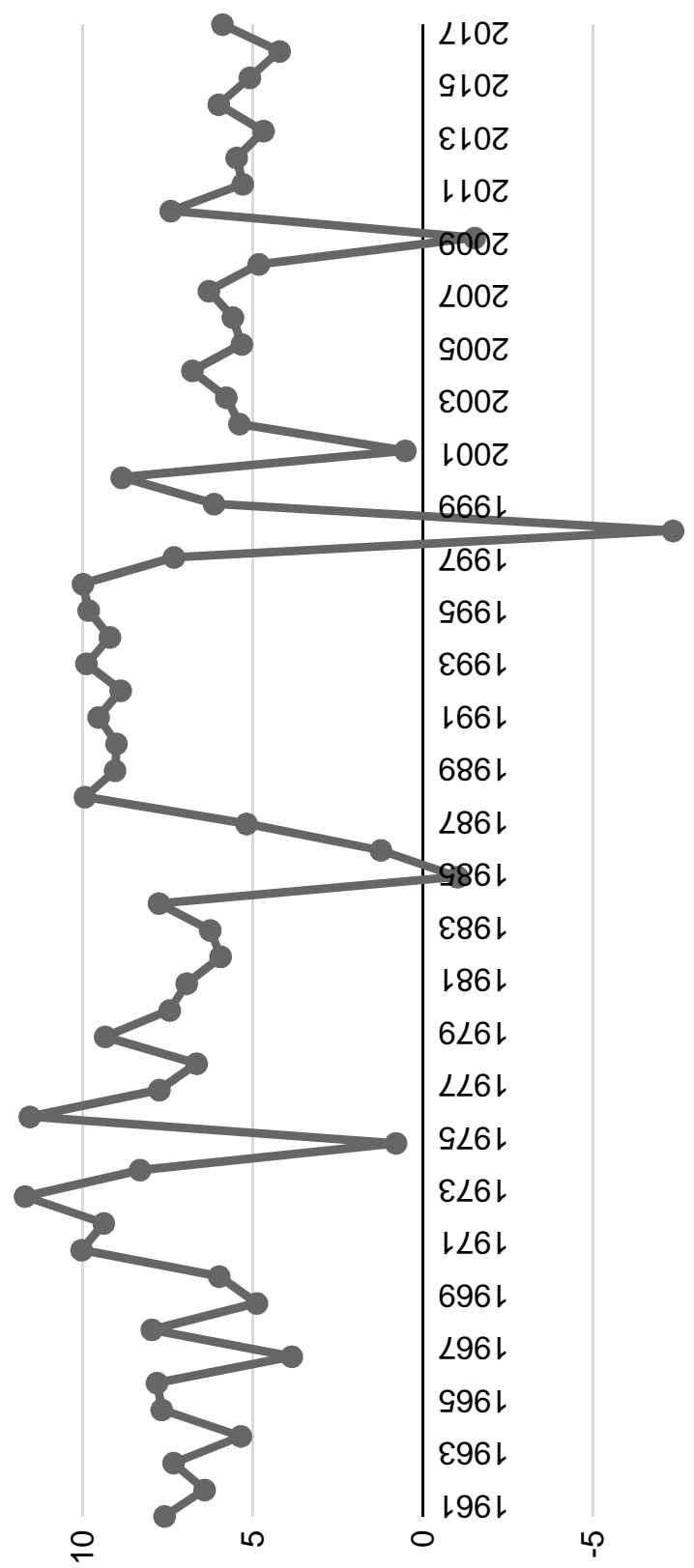

(\%)

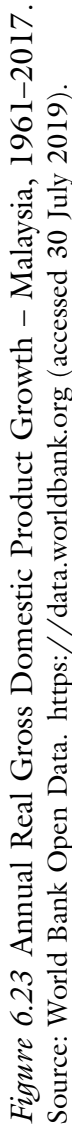


Table 6.5 Impact of Global Economic Shocks on the Malaysian Economy

\begin{tabular}{lll}
\hline Period & Event & Decline in economic growth (real GDP) \\
\hline $1973-1974$ & OPEC oil crisis & $8.3 \%(1974) \rightarrow 0.8 \%(1975)$ \\
$1985-1986$ & Commodity crisis & $7.8 \%(1984) \rightarrow-1.0 \%(1985)$ \\
$1997-1998$ & Asian financial crisis & $7.3 \%(1997) \rightarrow-7.4 \%(1998)$ \\
$2008-2009$ & Global financial crisis & $4.8 \%(2008) \rightarrow-1.5 \%(2009)$ \\
\hline
\end{tabular}

Source: World Bank Open Data. https://data.worldbank.org (accessed 30 July 2019).

GDP $=$ gross domestic product, $\mathrm{OPEC}=$ Organization of the Petroleum Exporting Countries.

foreign investors, causing sharp withdrawals from equity markets in the region including Malaysia. This was accompanied by a speculative attack on the ringgit. The financial liberalisation in the 1990s was an important precursor to this crisis. Unlike the previous two crises, this crisis was primarily due to financial globalisation.

The fourth and more recent crisis, the global financial crisis (2008-09), was originally caused by the deterioration of sub-prime assets in the US, which subsequently led to systemic liquidity problems in the global interbank and credit markets. This brought about deleveraging activities and recessions in developed economies. Malaysia's exposure to this crisis was primarily through the weakened demand for the country's exports as well as the decline (following deleveraging activities) in foreign investments.

Given the different nature and impact of each of these economic crises, it is not surprising that the policy responses from the Malaysian government have been different (Athukorala, 2010). These policy responses depend on both external constraints (e.g. speed of global economic recovery) as well as internal constraints (e.g. socioeconomic policies and fiscal space). There are also intertemporal dependence and learning effects over time for policy makers. For example, the restructuring of the financial and corporate sectors in Malaysia during the aftermath of the Asian financial crisis strengthened the ability of the country's financial sector to cope with the effects of the global financial crisis.

In summary, the openness of the Malaysian economy made it vulnerable to global economic shocks. Prior to the 1990s, the crises were mainly transmitted through the trade sector; however, since liberalising its financial sector in the 1990s, the Malaysian economy became vulnerable to external shocks to both the trade and financial sectors.

\subsection{Institutions}

Institutions are today recognised as an important factor in economic growth (Acemoglu, Johnson, and Robinson, 2005). In the context of globalisation, institutions are also an important source of comparative advantage (Levchenko, 2007; Costinot, 2009). Within this literature, the traditional way of conceptualising institutions is in terms of the enforcement of contracts and property 


\section{Cassey Lee}

rights. In addition to these, the transaction costs of exporting and importing could also be affected by the quality of institutions. For example, rampant corruption in customs could increase importing and exporting costs. The implementation of trade facilitation measures could also be slowed as such measures could be perceived as reducing opportunities for corruption. Aside from transaction costs, the benefits of trade could also be reduced by corruption. For example, as a result of corruption, importers have to pay higher import costs that are then passed on to consumers. Corruption can also make it easier to smuggle goods into the country, resulting in the loss of government revenues.

In the case of Malaysia, there is a scarcity of empirical research on how trade is affected by problems related to the quality of institutions (e.g. corruption). There is anecdotal evidence but hardly any empirical quantitative studies on this issue. ${ }^{3}$ Fortunately, the World Bank provides some statistics on the extent of corruption in relation to import licences (Table 6.6). Table 6.6 shows that the incidence of corruption (as measured by the percentage of firms expected to give gifts to obtain import permits) is fairly high in some industries in Malaysia, such as garments. Interestingly, the incidence of corruption amongst non-exporters is much higher than amongst exporters. However, firms with foreign ownership tend to experience a higher incidence of corruption compared to domestic firms.

The above statistics suggest that there is significant room for improvement in the area of corruption in trade-related activities. This topic is especially worth highlighting given the recent developments in Malaysian politics. One of the most significant events in Malaysia since the country's independence was the shock defeat of the ruling political party coalition, Barisan Nasional, in the 14th general election held on 9 May 2018. Prior to its defeat, Barisan Nasional had ruled the country continuously since 1957. A key reason for the end of Barisan Nasional's rule was the deterioration in institutions and governance in the country, which led to massive rent-seeking and corruption. A key item on the

Table 6.6 Globalisation and Incidence of Corruption in Malaysia, 2015

\begin{tabular}{ll}
\hline Subgroup level & $\begin{array}{l}\text { Percent of firms expected to give gifts to get } \\
\text { an import license }\end{array}$ \\
\hline All & 39.0 \\
Food & 24.6 \\
Garments & 74.6 \\
Chemicals and chemical products & 12.7 \\
Electronics and communications & 34.0 \\
$\quad$ equipment & 38.4 \\
Other manufacturing & 28.0 \\
Direct exports are 10\% or more of sales & 47.9 \\
Non-exporter & 39.9 \\
Domestic & 49.3 \\
10\% or more foreign ownership & \\
\hline
\end{tabular}

Source: World Bank - Doing Business Data. https://www.doingbusiness.org/en/data (accessed 30 July 2019). 
agenda of the new Pakatan Harapan government is institutional reforms, which are largely aimed at improving economic and political governance in Malaysia. These are likely to include reductions in the incidence of corruption in import and export activities. If such reforms materialise, Malaysia's competitiveness as an export-oriented manufacturing base and as a trading nation is likely to improve.

\section{Conclusions}

Globalisation has, without any doubt, had a very significant impact on Malaysia. The country's engagement in globalisation can be traced to the pre-independence period. This engagement - through trade and labour migration flows - helped shaped the country as it is today. The multi-ethnic nature of its society and its development into an upper middle-income economy were both driven by globalisation. The country's economic openness in terms of trade and investment brought about the development of an export-oriented manufacturing economy. Evidence from microdata research indicates that productivity and innovation are positively related to exporting in the manufacturing sector. However, these studies also indicate that there are weaknesses in terms of FDI spillovers and knowledge flows. Due to these problems, and possibly others, it is not surprising that premature deindustrialisation has been a problem since the late 1990s. This problem has been compounded by an over-dependence on low-skilled foreign labour. Extensive government ownership in the services sector to achieve affirmative action and wealth redistribution goals could also have limited the sector's potential contributions to economic growth. This could have adversely affected the productivity of the services sector and limited the country's participation in new regional trade agreements. One cost of engagement with the global economy is economic instability. All four major global economic crises in the post-war period have adversely affected the Malaysian economy. The transmission mechanisms of these crises have differed due to differences in the sources of these crises as well as changes in the Malaysian economy over time. Despite such risks from globalisation, disengaging from globalisation is not an option for the Malaysian economy due to its small size. From a policy perspective, better institutions and policy instruments are needed to cope with the risks arising from globalisation. Improvements in institutions are also likely to improve Malaysia's trade competitiveness further.

\section{Notes}

1 The Dutch ceded their control over Melaka to the British between 1795 and 1816 during the Napoleonic Wars (1795-1815).

2 Under the Resident System, state revenues were under the control of British advisors.

3 In a 2014 statement by customs, it was reported that RMl.67 billion worth of cigarettes and alcohol had been smuggled into Malaysia since 2011. See 'Corrupt 
M'sian customs officers: Lavish lifestyle gave them away', AsiaOne, 7 September 2014.

\section{References}

Acemoglu, D., S. Johnson, and J. Robinson (2005), 'Institutions as a Fundamental Cause of Long-Run Growth', in P. Aghion and S.N. Durlauf (eds.), Handbook of Economic Growth, Vol 1A. Amsterdam: Elsevier B.V.

Adnan, M.A. (1982), 'Extractive Industries', in E.K. Fisk and H. Osman-Rani (eds.), The Political Economy of Malaysia. Kuala Lumpur: Oxford University Press.

Ahmad, Z.B. and S. Rashid (1999), 'Exports, Imports and Economic Growth in Malaysia: Empirical Evidence Based on Multivariate Time Series', Asian Economic Journal, 13(4), pp.389-406.Athukorala, P.-C. (2010), 'Malaysian Economy in Three Crises', Working Paper, No. 2010/12. Canberra: Australian National University, Arndt-Corden Department of Economics.

Athukorala, P.-C. and E. Devadason (2012), 'The Impact of Foreign Labor on Host Country Wages: The Experience of a Southern Host, Malaysia', World Development, 40(8), pp.1497-1510.

Brawley, M. (2009), 'Globalization', in K.A. Reinert, R.S. Rajan, A.J. Glass, and L.S. Davis (eds.), Princeton Encyclopaedia of the World Economy. Princeton, NJ: Princeton University Press.

Bruton, H.J. (1992), The Political Economy of Poverty, Equity and Growth: Sri Lanka and Malaysia. Washington, DC: World Bank.

Chai, H.-C. (1967), The Development of British Malaya 1896-1909, 2nd Edition. Kuala Lumpur: Oxford University Press.

Cho, G. (1990), The Malaysian Economy: Spatial Perspectives. London: Routledge.

Chuah, L.L., N. Loayza, and N.H. Minh (2018), 'Resource Misallocation and Productivity Gaps in Malaysia', Policy Research Working Paper, No. 8368. Washington, DC: World Bank Group.

Costinot, A. (2009), 'On the Origins of Comparative Advantage', Journal of International Economics, 77(2), pp.255-264.

Dogan, E., W.K. Nyen, and M. Yap (2011), 'Does Exporter Turnover Contribute to Aggregate Productivity Growth? Evidence from Malaysian Manufacturing', World Economy, 34(3), pp.424-443.

Dogan, E., W.K. Nyen, and M. Yap (2017), 'Vertical and Horizontal Spillovers from Foreign Direct Investment: Evidence from Malaysian Manufacturing', Asian Economic Papers, 16, pp.158-183.

Drabble, J.H. (2000), An Economic History of Malaysia: The Transition to Modern Economic Growth. London: Macmillan.

Fong, C.-O. (1989), The Malaysia Economic Challenge in the 1990s: Transformation for Growth. Singapore: Longman.

Gomez, T., T. Padmanabhan, N. Kamaruddin, S. Bhalla, and F. Fisal (2017), Minister of Finance Incorporated: Ownership and Control of Corporate Malaysia. London: Palgrave MacMillan.

Henderson, V. (2002), 'Urbanization in Developing Countries', World Bank Research Observer, 17(1), pp.89-112.

International Tin Research Institute (2011), 'Historical Trends in Tin Production', mimeo. 
Jomo, K.S. (1990), Growth and Structural Change in the Malaysian Economy. London: Macmillan.

Keong, C.-C., Z. Yusopa, and V. Khim-Sen (2003), 'Export-Led Growth Hypothesis in Malaysia: An Application of Two-Stage Least Square Technique', mimeo.

Lee, C. (2004), 'The Determinants of Innovation in the Malaysian Manufacturing Sector: An Econometric Analysis at the Firm Level', ASEAN Economic Bulletin, $21(3)$, pp.319-329.

Lee, C. (2011a), 'Trade, Productivity, and Innovation: Firm-Level Evidence from Malaysian Manufacturing', Journal of Asian Economics, 22(4), pp.284-294.

Lee, C. (2011b), 'Knowledge Flows, Organization and Innovation: Firm-Level Evidence from Malaysia', in C.H. Hahn and D. Narjoko (eds.), Globalization and Innovation in East Asia. Economic Research Institute for ASEAN and East Asia (ERIA) Research Project Report, 2010(4), pp.370-409. Jakarta: ERIA.

Lee, C. (2012), 'Exporting, Productivity, Innovation and Organization: Evidence from Malaysia Manufacturing', in C.H. Hahn and D.A. Narjoko (eds.), Dynamics of Firm Selection Process in Globalized Economies. ERIA Research Project Report, $2011(3)$, pp.289-305.

Lee, C. (2013), 'Globalization and Wage Inequality: Firm Level Evidence from Malaysia', in C.H. Hahn and D.A. Narjoko (eds.), Impact of Globalization on Labor Market. ERIA Research Project Report, 2012(4), pp.197-231.

Lee, C. (2014), 'The Exporting and Productivity Nexus: Does Firm Size Matter?' Globalization and Performance of Small and Large Firms, in C.H. Hahn and D.A. Narjoko (eds.). ERIA Research Project Report, 2013(3), pp.225-248.

Lee, C. (2018), 'Agglomeration, Human Capital and Foreign Labour: The Case of Malaysia', mimeo.

Lee, C. (2019), 'Manufacturing Performance and Services Inputs: Evidence from Malaysia', ISEAS Economics Working Paper, Vol. no. 2018-2, pp. 1-24.

Leete, R. (2007), Malaysia: From Kampung to Twin Towers. Kuala Lumpur: Oxford Fajar.

Levchenko, A.A. (2007), 'Institutional Quality and International Trade', Review of Economic Studies, 74(3), pp.791-819.

Lim, C.-Y. (1967), Economic Development of Modern Malaya. Kuala Lumpur: Oxford University Press.

Lim, H.-K. (1978), The Evolution of the Urban System in Malaysia. Kuala Lumpur: University of Malaya Press.

Makun, K. (2017), 'Trade Openness and Economic Growth in Malaysia: Some TimeSeries Analysis', Foreign Trade Review, 52(3), pp.157-170.

Malaysian Rubber Board (2016), Natural Rubber Statistics 2016. Kuala Lumpur: Malaysian Rubber Board.

Melitz, M. (2003), 'The Impact of Trade on Intra-Industry Reallocation and Aggregate Industry Productivity', Econometrica, 71(6), pp.1695-1725.

Menon, J. and T.H. Ng (2017), 'Do State-Owned Enterprises Crowd Out Private Investment? Firm Level Evidence from Malaysia', Journal of Southeast Asian Economies, 34(3), pp.507-522.

Mohamad, J. (2010), 'Wage Inequality and Trade Reforms in Malaysia', Paper presented at the International Conference on Applied Economics, Athens, Greece. 


\section{Cassey Lee}

Nazrin, S. (2017), Charting the Economy: Early 20th Century Malaya and Contemporary Malaysian Contrasts. Shah Alam: Oxford University Press.

Noor, A.K. and R. Adam (2009), 'Productivity Spillovers from FDI in Malaysian Manufacturing: Evidence from Micro-Panel Data', Asian Economic Journal, 2(2), pp.143-167.

Perkins, D. and W.-T. Woo (2000), 'Malaysia: Adjusting to Deep Integration with the World Economy', in J.D. Sachs and K. Schwab (eds.), The Asian Financial Crisis: Lessons for a Resilient Asia. Cambridge, MA: Massachusetts Institute of Technology Press.

Ragayah, M.Z. (2011), 'Poverty and Income Distribution', in R. Rasiah (ed.), Malaysian Economy. New York, NY: Oxford University Press.

Ragayah, M.Z. (2012), 'Poverty Eradication and Income Distribution', in H. Hill, T.S. Yean, and R.M. Zin (eds.), Malaysia's Development Challenges. London: Routledge.

Rasiah, R. (2006), 'Explaining Malaysia's Export Expansion in Palm Oil and Related Products', in V. Chandra (ed.), Technology, Adaptation and Exports. Washington, DC: World Bank.

Rasiah, R. (ed.) (2011), Malaysian Economy: Unfolding Growth and Social Change. Kuala Lumpur: Oxford University Press.

Said, R. and K.H. Hamid (2011), 'The Effects of Occupational Differentials: Between or Within Industrial Effects', International Journal of Economic Policy Studies, 6, pp.83-97.

Saw, S.-H. (2007), The Population of Malaysia. Singapore: Institute of Southeast Asian Studies.

Saw, S.-H. (2015), The Population of Malaysia, 2nd Edition. Singapore: Institute of Southeast Asian Studies.

Sidhu, M.S. and G.W. Jones (1981), Population Dynamics in a Plural Society: Peninsular Malaysia. Kuala Lumpur: University of Malaysia Cooperative Bookshop Publications.

Sulaiman, M. and N. Md. Saad (2009), 'An Analysis of Export Performance and Economic Growth of Malaysia Using CoIntegraton and Error Correction Models', Journal of Developing Areas, 43(1), pp.217-231.

World Bank (2012), Malaysia Economic Monitor: Modern Jobs. Kuala Lumpur: World Bank. 


\section{Appendix}

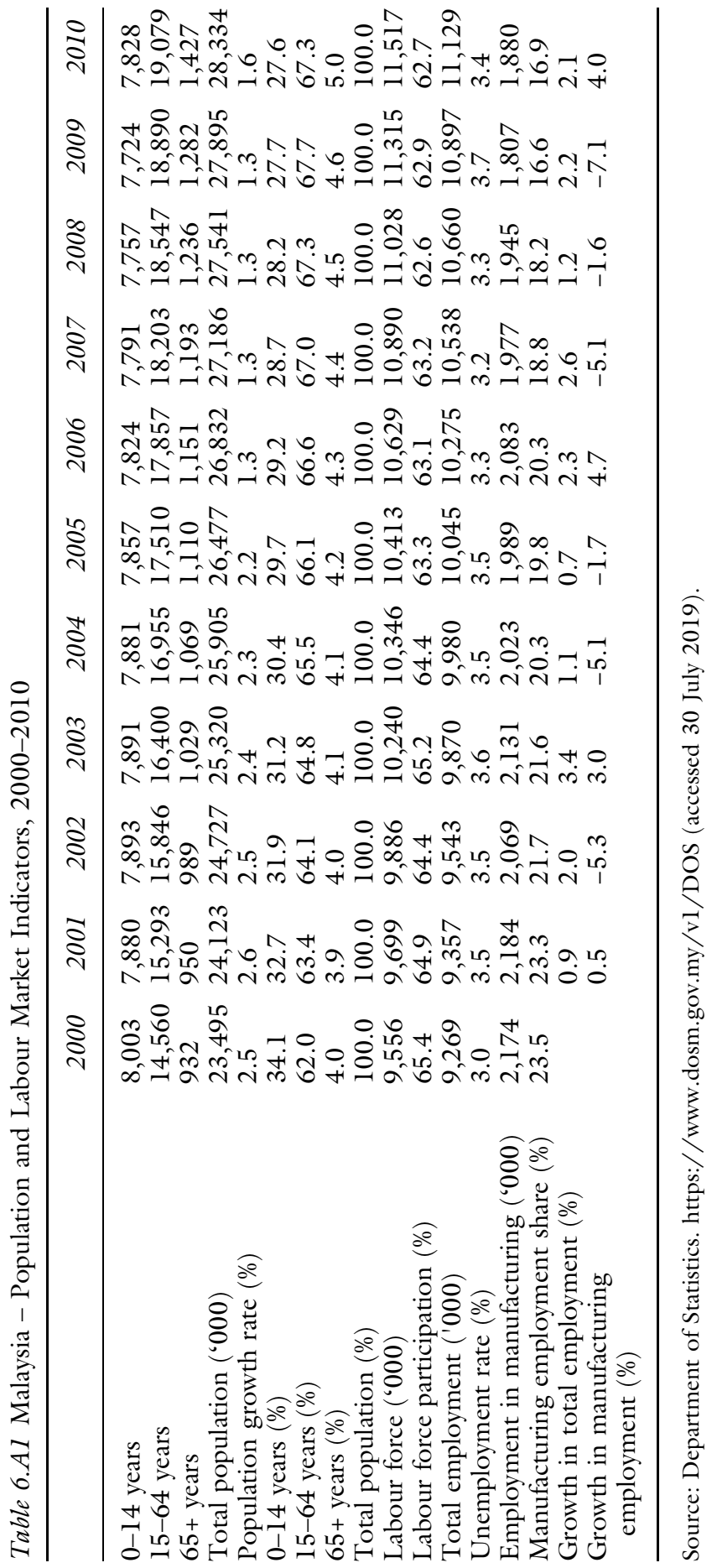

